\title{
Long-term trends in corn yields and soil carbon under diversified crop rotations
}

M. Jarecki, B. Grant, W. Smith, B. Deen, C. Drury, A. VanderZaag, B. Qian, J. Yang, and C. Wagner-Riddle

This is the peer reviewed version of the following article: Jarecki, M., Grant, B., Smith, W., et al. Long-term trends in corn yields and soil carbon under diversified crop rotations. J Environ Qual 47, 635-643 (2018). doi:10.2134/jeq2017.08.0317 which has been published in final form at https://doi.org/10.2134/jeq2017.08.0317. This article may be used for non-commercial purposes in accordance with Wiley Terms and Conditions for Use of Self-Archived Versions. 


\section{Long-term trends in corn yields and soil carbon under diversified crop rotations}

2 Marek Jarecki ${ }^{1}$, Brian Grant ${ }^{2}$, Ward Smith $^{2}$, Bill Deen $^{3}$, Craig Drury ${ }^{4}$, Andrew VanderZaag ${ }^{2}$,

3 Budong Qian ${ }^{2}$, Jingyi Yang ${ }^{4}$ and Claudia Wagner-Riddle ${ }^{1 *}$

$4 \quad{ }^{1}$ School of Environmental Sciences, University of Guelph, Guelph, ON, Canada; ${ }^{2}$ Ottawa

5 Research and Development Centre, Agriculture and Agri-Food Canada, Ottawa, ON, Canada;

$6 \quad{ }^{3}$ Department of Plant Agriculture, University of Guelph, Guelph, ON, Canada; ${ }^{4}$ Harrow

7 Research and Development Centre, Agriculture and Agri-Food Canada, Harrow, ON, Canada.

$8 \quad *$ corresponding author: cwagnerr@uoguelph.ca

9 Abbreviation list: SOC, soil organic carbon; CC, continuous corn; CCSS, corn-corn-soybean-

10 soybean; CCSW, corn-corn-soybean-winter wheat; CCSW+Rc, corn-corn-soybean-winter wheat

11 + red clover; CCAA, corn-corn-alfafa-alfalfa; COAA, corn-oats-alfalfa-alfalfa; RCP,

12 representative concentration pathways.

13 Keywords: Corn yield, Diversified crop rotation, DNDC model, Historical and future trends in

14 soil organic carbon

15 Core ideas:

16 - Corn grown in rotation had higher yield than grown in monoculture

17 - Improvements in the DNDC model captured the yield increases in diversified rotations

18 - Diversified rotations had higher SOC stock than corn in monoculture

19 - DNDC-predicted and observed values agreed well for yield and soil carbon

20

- Benefits from diversified rotations were predicted by DNDC for future scenarios 


\section{Abstract}

22 Agricultural practices such as including perennial alfalfa, winter wheat, or red clover in corn 23 rotations can provide higher crop yields and increase soil organic carbon (SOC) over time. How

24 well process-based biogeochemical models such as DNDC capture the beneficial effects of 25 diversified cropping systems is unclear. To calibrate and validate DNDC for simulation of 26 observed trends in corn yield and SOC we used long-term trials: continuous corn (CC) and corn27 oats-alfalfa-alfalfa (COAA) for Woodslee, ON, 1959-2015; continuous corn (CC), corn-corn28 soybean-soybean (CCSS), corn-corn-soybean-winter wheat (CCSW), corn-corn-soybean-winter 29 wheat + red clover (CCSW + Rc) and corn-corn-alfalfa-alfalfa (CCAA) for Elora, ON, 198130 2015. Yield and SOC under $21^{\text {st }}$ century conditions were projected under future climate scenarios 31 from 2016 to 2100 . The DNDC model was calibrated to improve crop nitrogen stress and was 32 revised to estimate changes in water availability as a function of soil properties. This improved 33 yield estimates for diversified rotations at Elora (mean absolute prediction error, MAPE, 34 decreased from $13.4-15.5 \%$ to $10.9-14.6 \%$ ) with lower errors for the 3 most diverse rotations. 35 Significant improvements in yield estimates were also simulated at Woodslee for COAA with 36 MAPE decreasing from 24.0 to $16.6 \%$. Predicted and observed SOC were in agreement for 37 simpler rotations (CC or CCSS) at both sites (53.8 and 53.3 $\mathrm{Mg} \mathrm{C}^{-1}$ for Elora; 52.0 and 51.4 $\mathrm{Mg} \mathrm{C} \mathrm{ha}{ }^{-1}$ for Woodslee). Predicted SOC increased due to rotation diversification and was close to observed values (58.4 and $59 \mathrm{Mg} \mathrm{C} \mathrm{ha}^{-1}$ for Elora; 63 and $61.1 \mathrm{Mg} \mathrm{C}^{-1}$ for Woodslee).

40 Under future climate scenarios the diversified rotations mitigated crop water stress resulting in 41 trends of higher yields and SOC content in comparison to simpler rotations. 
45 In contemporary agriculture, crops grown in rotation are often displaced by crops grown in 46 monocultures (Meyer-Aurich et al., 2006a; Liebman et al., 2013; Gaudin et al., 2015). This trend 47 is worrisome as long-term monoculture can lead to nutrient depletion and degradation of soil 48 quality (Karlen et al., 2013). Practices such as including perennial alfalfa, winter wheat, or red 49 clover in corn crop rotations have been shown to increase soil organic carbon (SOC), and to 50 produce higher and more stable crop yields over time (Meyer-Aurich et al., 2006a; Drury et al., 51 2008; Gaudin et al., 2013). Indeed, the positive influence of diversified rotations on crop 52 productivity and soil health has been demonstrated with long-term trials ( $>20$ years) (Congreves 53 et al., 2015). However, long-term field experiments represent limited sets of climate, soil and 54 crop management conditions. Accurate prediction of crop yields, nutrient dynamics, and SOC 55 sequestration in various conditions, including future climate scenarios can be achieved by 56 implementation of biogeochemical models, provided proper evaluation is carried out using 57 results from long-term trials (Grant et al., 2016). The DNDC biogeochemical model by Li et al. (2000) is a widely-recognized tool with a 59 large spectrum of simulated outputs. The DNDC model has been tested for its ability to predict 60 soil temperature, soil water content, soil nitrogen $(\mathrm{N})$ content, and nitrous oxide $\left(\mathrm{N}_{2} \mathrm{O}\right)$ emissions 61 at experimental sites in eastern and western Canada (Smith et al., 2002, 2008). It has also been 62 employed in multi-model comparisons for crop production and $\mathrm{N}_{2} \mathrm{O}$ emissions (Ehrhardt et al., 63 2017) and carbon (C) dynamics (Smith et al., 2012, Grant et al., 2016) along with assessing the 64 effects of climate change on crop production (Smith et al., 2013, He et al., 2017). These 65 investigations have prompted the development of improved model processes for the Canadian 66 version of DNDC (DNDC v.CAN) including crop biomass growth (Kröbel et al., 2011), 
67 evapotranspiration (Dutta et al., 2016a), soil temperature (Dutta et al., 2017), ammonia volatilization after slurry application (Congreves et al., 2016) and ammonia emissions after urea application (Dutta et al., 2016b). Although the DNDC model has been employed under a wide range of cropping systems in Canada (Abalos et al., 2013, Kröbel et al., 2011, Smith et al., 2012,

71 2013) and elsewhere (Ehrhardt et al., 2017; Brilli et al., 2107; Zhang and Niu, 2016), it has not

72 been utilized to specifically assess the effect of crop rotation diversity on corn yields and SOC under historical climate or future climate change.

Future atmospheric conditions will be characterized by increased variability in temperature and precipitation and elevated atmospheric carbon dioxide $\left(\mathrm{CO}_{2}\right)$ concentration (IPCC, 2007). Current evidence of more stable crop yields over time in diversified crop rotations

77 (Gaudin et al., 2013) and increased SOC (Meyer-Aurich et al., 2006b; Drury et al., 2008) suggests that these systems may be more suitable for future conditions than monocultures. IPCC 79 (2014) elaborated four representative concentration pathways (RCP) scenarios that can be used for assessing future predictions. The scenarios include a stringent mitigation scenario (RCP2.6),

81 two intermediate scenarios (RCP4.5 and RCP6.0) and one scenario with high greenhouse gas 82 emissions (RCP 8.5) based upon radiative forcing levels of 2.6, 4.5, 6.0 and $8.5 \mathrm{~W} \mathrm{~m}^{-2}$ by the end 83 of the $21^{\text {st }}$ century, respectively (Van Vuuren et al., 2011; IPCC, 2014). He et al (2017) 84 considered two contrasting scenarios: the intermediate RCP4.5 and high RCP8.5 as appropriate $8521^{\text {st }}$ century pathways for predicting crop yields and soil greenhouse gas emissions. No study to 86 trends in monoculture and in diversified rotations over time at two locations, and modify the 
90 predictions for corn monoculture and diversified rotations for two long-term field trials on

91 contrasting soil; (3) implement the improved DNDC model to predict corn yield and SOC

92 dynamics in various cropping systems over the $21^{\text {st }}$ century under future scenarios: RCP4.5 and

93 RCP8.5.

95 Materials and Methods

96

Site Description

97 Data from two long-term crop rotation trials with contrasting soil types located in Elora (35

98 years) and Woodslee (57 years), Ontario were selected for this study. The Elora trial was

99 established in 1981 at the Elora Research Station $\left(43^{\circ} 39^{\prime} \mathrm{N}, 80^{\circ} 25^{\prime} \mathrm{W}\right.$, elevation $\left.376 \mathrm{~m}\right)$ on a

100 Typic Hapludalf (Gray Brown Luvisol) silt loam soil (270, 560 and $170 \mathrm{~g} \mathrm{~kg}^{-1}$ of sand, silt and

101 clay, respectively), with pH of 7.3 and SOC of $22 \mathrm{~g} \mathrm{~kg}^{-1}$ (Ramnarine et al., 2014). The Woodslee

102 trial was established in 1959 at the Agricultural and Agri-Food Canada (AAFC) Experimental

103 Farm $\left(42^{\circ} 13^{`} \mathrm{~N}, 82^{\circ} 44^{\prime} \mathrm{W}\right.$, elevation $\left.186 \mathrm{~m}\right)$ on poorly drained Brookston clay loam, with 280,

104350 and $370 \mathrm{~g} \mathrm{~kg}^{-1}$ of sand, silt and clay, respectively, and $\mathrm{pH}$ of 6.1 and SOC of $25 \mathrm{~g} \mathrm{~kg}^{-1}$

105 (Drury et al., 1998; Tan et al., 2002). A complete description of sites and experiments is given in

106 Gaudin et al. (2015) for Elora and Drury and Tan (1995) for Woodslee. Climate characteristics

107 are shown in Table S2 and Fig S1.

108

109 Cropping Systems

110 Five cropping systems were selected from the Elora trial: continuous corn (Zea mays L.)

111 monoculture (CC), corn-corn-soybean-soybean (Glycine max L.) (CCSS), corn-corn-soybean- 
112 winter wheat (Triticum aestivum L.) (CCSW), corn-corn-soybean-winter wheat with red clover

113 (Trifolium pratense L.) as a cover crop inter-seeded under wheat (CCSW+Rc) and corn-corn-

114 alfalfa-alfalfa (Medicago sativa L.) (CCAA). For Woodslee, two cropping systems were

115 studied: corn monoculture and corn-oats (Avena sativa)-alfalfa-alfalfa. Both sites were managed

116 with conventional tillage which consisted of fall moldboard plowing and disking in spring before

117 planting annual crops and first-year alfalfa (Table S1). Nitrogen fertilizer was applied as starter

118 at planting and as side-dress at the corn $6^{\text {th }}$ leaf stage (Table S1). Details on other agronomic

119 practices are given in Gaudin et al. (2015) for Elora and in Drury and Tan (1995) for Woodslee.

\section{DNDC Model Description}

122 The DNDC model framework includes processes for soil, climate, crop production, $\mathrm{C}$ and $\mathrm{N}$ 123 dynamics, and trace gas emissions reported at a daily time step. Model inputs are setup based on 124 readily available measurements to characterize soil characteristics (bulk density, texture, soil 125 hydraulic parameters, SOC), climate (air temperature, precipitation, wind speed, solar radiation, 126 humidity), crop production (crop type, potential yield, biomass fractions, C:N ratio, water

127 demand, optimal temperature) and agricultural management (tillage, residue, irrigation, 128 plant/harvest dates, fertilizer).

129 Crop production is regulated using a simple optimal C growth function driven by temperature 130 degree days. The optimal production is reduced by $\mathrm{N}$ and water availability, temperature stress 131 based on a cardinal approach developed in Canada (Yan and Hunt, 1999) and heat stress during 132 anthesis (Smith et al., 2013). The model was updated to include information from Free-Air $\mathrm{CO}_{2}$ 133 Enrichment studies regarding the effects of $\mathrm{CO}_{2}$ on $\mathrm{C}$ assimilation in plants, crop water use 
134 efficiency, and crop $\mathrm{N}$ use (Smith et al., 2013). Crop C inputs and C dynamics are managed by

135 the $\mathrm{C}$ decomposition sub-model which is characterized by four major pools (litter, labile humus,

136 passive humus and microbial biomass). Each pool utilizes a predefined base decomposition rate

137 that is modified as a function of soil texture, moisture, temperature and $\mathrm{N}$ content. A more

138 detailed description of the model's mechanisms and framework design can be found in Li et al.

139 (2012) and Grant et al. (2016).

142 Long-term daily temperature, precipitation, solar radiation, wind speed and relative humidity 143 data were obtained from Environment Canada (2017), Elora Research Meteorological Station

144 and from the Harrow Experimental Farm AAFC records. The two sites had slightly different 145 climatic conditions with Elora over 1981-2015 being slightly cooler (growing degree days 1009 146 vs. 1405) and wetter (annual precipitation 1009 vs. $844 \mathrm{~mm}$ ) than Woodslee over 1959-2015 147 (Table S2). Inputs of soil physical properties, planting, fertilization, and tillage operations were 148 obtained from Gaudin et al. (2015) for Elora and from Drury et al. (1995) for Woodslee (Table 149 S1).

152 The model simulations were parameterized to ensure that appropriate $\mathrm{C}$ residue inputs from corn, 153 winter wheat, soybean and alfalfa were being returned to the soil. Initial calibration of crop 154 parameters (biomass fractions) were leveraged from Janzen et al. (2003) and Bolinder et al. 155 (2007) with some slight adjustment to get the best calibration fit for yields. Crop N uptake and 
156 removal was managed through adjustment of crop biomass $\mathrm{C}: \mathrm{N}$ ratios to ensure that the soil $\mathrm{N}$

157 status would result in a slight $\mathrm{N}$ stress under the continuous corn simulations. Yield parameter

158 calibration was conducted using the CCSW rotation at Elora and the first 10 years of the CC

159 rotation at Woodslee (Tables1 and S3). No other calibration was conducted.

It has been reported that under diverse crop rotations certain soil properties may be

161

162

163

164

165

166

167

168

impacted including, soil pore space, bulk density and biopore volume all of which could influence soil water availability (Bolton et al., 1982; Drury and Tan, 1995; Munkholm et al., 2013; Gaudin et al., 2015). To account for these effects, we incorporated a pedo-transfer function to recalculate changes in soil properties based on changes in SOC (Saxton and Rawls, 2006). These changes in soil properties were applied as relative differences to ensure that initial measured bulk densities and soil hydraulic properties could be utilized. Observed crop yields were compared to simulated values using the standard DNDC model (DNDC 'before') and after the revision to account for increased $\mathrm{N}$ stress under continuous corn using slightly lower $\mathrm{C}: \mathrm{N}$ ratio (grain $\mathrm{C}: \mathrm{N}$ adjusted from 35 to 30 ) and the improved water availability through the use of the pedo-transfer function (DNDC 'after').

To ensure that each of the cropping systems had similar $\mathrm{N}$ stress levels under future climate we also developed a new "Farm Agent" algorithm to manage future crop N stress. Using a 10-year running average of the crop $\mathrm{N}$ stress index ( $\mathrm{N}$ uptake/ $\mathrm{N}$ demand) the farm agent would apply up to $10 \%$ change in fertilizer annually to ensure that the climate induced impacts of improved growth potential, increased $\mathrm{N}$ leaching, higher $\mathrm{N}$ mineralization and trace gas losses did not induce high crop $\mathrm{N}$ stress. This generally resulted in higher $\mathrm{N}$ fertilizer rates being applied under future conditions. 
DNDC performance was validated by comparing observed and simulated corn yield for 35 years at Elora and 57 years at Woodslee. For SOC, in years with accessible data, the comparison between measured and simulated $\mathrm{C}$ concentration and $\mathrm{C}$ stock in the soil profile was completed.

183 Observed SOC concentration and stock were utilized from published data for the top 0-0.20 $\mathrm{m}$ or 184 for 0-0.50 m depending on data availability (Table S4). A record of SOC measurements was 185 available for selected rotations and from different sources for Elora. Data from 1995 were 186 available from Wanniarachchi et al. (1999); for 2005 from Yang et al. (2008). Data for 1998, 1872000 and 2015 were derived directly from experimental documentation (Deen, 2017).

188 Depending on the rotation, SOC concentration measurements were available in the following 189 years: for CC in 1995, 1998, 2000, 2005; for CCSS and CCSW in 1998, 2000 and 2015; for 190 CCSW+Rc in 1998 and 2000; and for CCAA in 2000 and 2015 (Table S1). For Woodslee, SOC 191 measurements included years 1994, 2002 and 2004-2007 (Drury et. al., 1998; Drury et al., 2004; 192 Reynolds et al., 2014).

$$
\mathrm{SOC}_{i}=\rho_{i} C_{i} L_{i} \times 10
$$
where $\rho_{\mathrm{i}}$ is the bulk density of the soil layer $\left(\mathrm{Mg} \mathrm{m}^{-3}\right), \mathrm{C}_{\mathrm{i}}$ is the organic carbon concentration of 199 the soil layer (mg C g ${ }^{-1}$ dry soil), $\mathrm{L}_{\mathrm{i}}$ is the length of soil layer (m) and 10 is a unit conversion 200 factor. The SOC stock was computed for 0-0.2 $\mathrm{m}$ and 0.2-0.5 $\mathrm{m}$ soil layers depending on data 201 availability. Total SOC stock for the soil was calculated by adding up all SOC for each soil layer 
202 in the profile. When the density of a particular core segment was not reported, the Saxton soil 203 water characteristic calculator was employed with soil texture and SOC concentration as input 204 data (Saxton and Rawls, 2009).

205 Agreement between observed and predicted corn yield values was evaluated using the 206 following statistical evaluators: mean absolute percentage error (MAPE, \%), root mean squared 207 error (RMSE), the Nash-Sutcliffe model efficiency (EF) (Nash and Sutcliffe, 1970) and the 208 coefficient of determination $\left(R^{2}\right)$, each defined as follows:

$209 \quad \mathrm{MAPE}=\frac{100}{n} \sum_{t=1}^{n}\left|\frac{o_{t}-p_{t}}{o_{t}}\right|$

210 Where $t$ is time step (year), $o_{t}$ is the observed value of the quantity being predicted, $p_{t}$ is the 211 predicted value, and $n$ is the number of years with available data;

$212 \quad \operatorname{RMSE}=\left[n^{-1} \sum_{t=1}^{n}\left(p_{t}-o_{t}\right)^{2}\right]^{0.5}$

$213 E F=\frac{\sum_{t=1}^{n}\left(o_{t}-\bar{o}\right)^{2}-\sum_{t=1}^{n}\left(p_{t-} o_{t}\right)^{2}}{\sum_{t=1}^{n}\left(o_{t}-\bar{o}\right)^{2}}$

214 and $\overline{\mathrm{o}}$ is the mean of the observed data. Model efficiency $\mathrm{EF}=1$ indicates full agreement between 215 the predicted and observed data, whereas $\mathrm{EF}<0$ indicates that predicted values are worse than 216 the observed mean $(\overline{0})$. treatment replication both of measured and simulated values; however, the standard error of the mean was used to infer if predicted SOC concentration means were different between cropping 220 systems (Reynolds et al. 2014). 
223 The variations in yield and SOC stock over time were simulated by DNDC for the historical 224 climate during the trial period (1981-2015 in Elora and 1959-2015 in Woodslee) and for future 225 climate scenarios over the $21^{\text {st }}$ century (2016-2100). Two scenarios were selected from the four 226 simulated RCPs: RCP4.5 which represents a medium stabilization scenario and RCP8.5 which 227 represents a very high baseline emission scenario. Temperature, precipitation and atmospheric $228 \mathrm{CO}_{2}$ concentration for these climate scenarios are listed in Table S5.

230 RCP8.5 scenarios, a linear regression analysis with time as an independent factor was used 231 (Sellers and Zenter, 1993). Significance of the difference between two slopes ( $t$ value) was 232 calculated using:

$233 \quad t=\frac{b_{1}-b_{2}}{\sqrt{s_{b 1}^{2}+s_{b 2}^{2}}}, d f=n_{1}+n_{2}-4$

234 where $b_{1}$ and $b_{2}$ are the slopes of regressions 1 and 2, and $s_{b 1}$ and $s_{b 2}$ are the standard errors for

235 these slopes, $d f$ is degrees of freedom based on $n_{1}$ and $n_{2}$ which are the sample sizes for 236 regression 1 and 2 (Soper, 2017).

\section{Results and Discussion}

Long-term yield variation

240 Variation in yield over time both in Elora and Woodslee was high. In Elora over 35 years, the

241 differences between the lowest and peak corn yield varied depending on cropping system from

2422.3 times in CC (5.04 Mg ha ${ }^{-1}$ in 1992 vs $11.74 \mathrm{Mg} \mathrm{ha}^{-1}$ in 2013 with a mean $=8.57$ and $\sigma=1.69$ 
$243 \mathrm{Mg} \mathrm{ha}^{-1}$ ) to 2.9 times in CCAA (4.85 in 1992 vs 13.96 in 2008 with a mean $=9.21$ and $\sigma=1.86$

$244 \mathrm{Mg} \mathrm{ha}^{-1}$ ) (Figure 1, Table 1). Expressed as coefficient of variation (CV) the variability in yield

245 was similar for these two cropping systems (CC and CCAA) at $20 \%$. In Woodslee, annual corn

246 yield experienced greater amplitude than in Elora. For corn yield in CC over 57 years, the

247 observed maximum yield was 8.5 times greater than the lowest (9.82 in $1992 \mathrm{vs} 1.15 \mathrm{Mg} \mathrm{ha}^{-1}$ in

2481999 with an average of 5.99 and $\sigma=1.74 \mathrm{Mg} \mathrm{ha}^{-1}$ ) (Figure 2, Table 1). The COAA cropping

249 system markedly increased both minimum and maximum corn yield with peak yield only 3.4

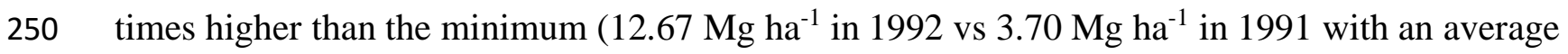

251 of 8.22 and $\sigma=2.00 \mathrm{Mg} \mathrm{ha}^{-1}$ ) (Figure 2, Table 1). The CV for yield over 57 years was $29 \%$ for

252 CC and $24.3 \%$ for COAA, highlighting the more stable yields over time for the diversified

253 rotation at this site.

Comparison between observed and DNDC-predicted corn yield in monoculture and in

256 diversified crop rotations

257 Changes to DNDC enhanced agreement between observed and predicted results at Elora for

258 CCSS, CCSW, CCSW+Rc and CCAA rotations, expressed in lower deviation (RMSE and

259 MAPE), greater $R^{2}$ and better model efficiency (EF) (Table 1). In Woodslee, model revision

260 (DNDC 'after') was captured the significant improvement in yield over time observed for corn

261 grown in rotation with oats and alfalfa (COAA) while DNDC 'before' did not predict this

262 increase in yield over time (Fig. 2b). Consequently, RMSE and MAPE were reduced, $R^{2}$ became 263 more significant (0.38) and model efficiency increase from negative to 0.21 (Table 1). Results

264 for $\mathrm{CC}\left(R^{2}=0.40\right.$ and EF 0.35 , Table 1$)$ were better than previously reported for Woodslee by

265 Liu et al. (2010) $\left(R^{2}=0.36\right.$ and EF $\left.=-0.70\right)$ with the DSSAT-CERES-Maize model. Simulations 
over shorter time periods (4-6 years) have shown better agreement with observed yield for the Woodslee site (Liu et al. 2014; He et al. 2017). However, our RMSE values are slightly better than obtained with the crop model BioStar in Germany $\left(2.1 \mathrm{Mg} \mathrm{ha}^{-1}\right)$ for corn yield (Bauböck, 2014). Large year to year variation in yield due to weather variability and potentially other factors, such as disease and pest incidence, over the long duration of the simulation period provided the most challenging aspect in good yield prediction performed by DNDC.

\section{Comparison between observed and DNDC-predicted soil organic carbon}

Distribution of predicted SOC concentration in the soil profile was evaluated for $\mathrm{CC}$ at both sites and COAA at Woodslee, as profile data was not available for the other cropping systems. Although DNDC predicted higher than measured SOC concentration for 0.20 to $0.40 \mathrm{~m}$ depth at both sites (Fig. S2), SOC stock in the 0-0.5 m depth agreed well between measured and predicted values in 1998, 2000, 2005 and 2015, with 17\% lower than predicted values for Elora CC (Fig. S3). At Woodslee, the $0-0.50 \mathrm{~m}$ carbon stock predicted by DNDC was very close to observed values for CC and COAA (Fig S3). Measured and DNDC-predicted 0-0.5 m SOC stock for CC at Elora over all available years agreed well at $82.1 \mathrm{Mg} \mathrm{C} \mathrm{ha}^{-1}\left(\sigma=5.97 \mathrm{Mg} \mathrm{C}^{-1}\right)$ and $84.0 \mathrm{Mg}$ $\mathrm{C} \mathrm{ha}{ }^{-1}\left(\sigma=0.68 \mathrm{Mg} \mathrm{Cha}^{-1}\right)$, respectively. For Woodslee, mean observed 0-0.5 m SOC stock was

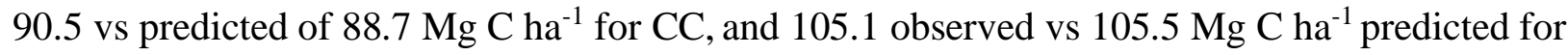
COAA. Smith et al. (2012) simulated SOC change in residue removal experiments for 14 sites (11 in Western Canada, 1 in Guelph, ON, and 2 in the mid-western USA). They observed DNDC slightly underestimated changes in SOC between cropping systems but differences in relation to observations remained within the $95 \%$ confidence limits, demonstrating the ability of DNDC in predicting reasonable SOC stock values. 
Increased SOC stocks after long-term diversified crop rotations were predicted well by

290

291

292

293

294

295

296

297

298

299

300

301

302

303

304

305

306

307

308

309

310

311

the DNDC model at both sites (Table 2). At Elora, observed and predicted 0-0.2 $\mathrm{m}$ SOC stocks

for simpler rotations (CC and CCSS) averaged 53.8 and 53.3 $\mathrm{Mg} \mathrm{C} \mathrm{ha}^{-1}$, while diversified rotations (CCSW, CCSW+Rc and CCAA) were 58.4 and $59 \mathrm{Mg} \mathrm{C} \mathrm{ha}^{-1}$, respectively (Table 2).

The largest discrepancy between observed and modelled SOC stock was observed for CCAA with slightly higher observed (4\%) than predicted value (58.26 vs 55.81 Mg C ha-1 , Table 2).

For Woodslee, predicted and measured 0-0.2 m SOC stocks were very similar (Table 2), and both showed increased SOC for the diversified rotation COAA in comparison to CC (Table 2).

The modelling results agree with previous observations at the Woodslee site showing higher SOC stock in COAA than in CC (Drury et. al., 1998; Drury et al., 2004; Reynolds et al., 2014).

Reynolds et al. (2014) described the COAA rotation as having minimal to moderate soil degradation, whereas CC presented excessive degradation relative to uncultivated soil. In general, SOC sequestration has been observed to be higher in crop rotations than in monocultures due to high production of crop residues and differences in crop residue quality (Franzluebbers et al., 1995; Drury et al. 1998).

\section{Simulations for future climate scenarios}

Simulations for future climate over the $21^{\text {st }}$ century (2016-2100) using RCP4.5 showed distinct changes in yields and associated SOC stocks between cropping systems both in Elora and Woodslee (Fig. 3). For Elora, CC and CCSS did not show any trend (regression was not significant) over time and the corn yields were at the same level until the end of the $21^{\text {st }}$ century (Fig. 3a, Table 3). DNDC predicted lower corn yield for CC and CCSS contrasted with CCSW, CCSW+Rc and CCAA where the yield was high. For CCSW, CCSW+Rc and CCAA, a 
312 significant increase in corn yield was observed over the first 45 years of simulation (until 2060).

313 For the remaining time (2060-2100) corn yield levelled off (Fig. 3a). An increase in yield over

314 time was noted in CCSW, CCSW+Rc and CCAA with larger increases for CCAA compared to

315 CCSW or CCSW+Rc as indicated by significant differences in slopes (Table 3). Meyer-Aurich

316 et al. (2006a) did observe improved yields at Elora when wheat was included in a corn-soybean

317 rotation but underseeding red clover into wheat had no effect on yields.

Decreased 0-0.2 m SOC stocks were predicted for CC and CCSS at Elora, with larger

319 decreases for the CCSS rotation (Fig 3b, Table 3). Such trend was observed with measured

320 values where SOC stock in the 0-0.34 m soil layer was less for CCSS than in CCAA (Meyer-

321 Aurich et al. (2006b). In contrast, more diversified rotations had the largest increases in SOC

322 stock over time: $\mathrm{CCSW}+\mathrm{Rc}>\mathrm{CCAA}>\mathrm{CCSW}$ (Fig. 3b, Table 3). Results from Iowa

323 (Farahbakhshazad et al., 2008) showed that DNDC-modelled soil carbon storage increased over

32420 years when cover crops were added to a corn-soybean rotation, due to higher biomass $\mathrm{C}$ input,

325 although crop yields stayed the same. Farahbakhshazad et al., (2008) used the DNDC model to

326 explore how alternative cropping practices affect environmental processes such as SOC storage

327 and nitrate leaching, but extensive validation of C inputs and SOC was not conducted for a range

328 of cropping systems.

Our findings that corn yields and SOC may increase in the future under diversified

330 rotations, relative to monoculture and CCSS, is an important result that has not been

331 demonstrated in other modelling studies in Canada. The results are plausible considering DNDC

332 was validated using long-term experimental data which already included variability in climate

333 and marginal increases in atmospheric $\mathrm{CO}_{2}$ concentration. The improved performance in the

334 diversified rotations is strongly related to crop water stress. Although precipitation increases 
under the climate scenarios, the simulated evapotranspiration increases at a greater rate at higher temperatures. Note that the Canada DNDC model has recently been improved and validated for

337 simulating evapotranspiration in eastern Canada (Dutta et al., 2016a). Some crops have lower

338 water requirements than corn (such as oats) or are grown in periods where more water is

339 available due to low soil evaporation at cooler temperatures (such as winter wheat or red clover).

340 This reduces water stress in the system and promotes higher growth which increases residue C

341 inputs. As a consequence, SOC under climate change is predicted to decline slightly under CC

342 and the CCSS rotation (soybean has high water use/biomass and low soil carbon inputs), but to

343 increase under the diversified rotations. The increased evaporative stress for the rotational corn is

344 offset by reduced or more efficient water use by the other crops but also by the higher soil water

345 holding capacity calculated by the revised DNDC model as SOC increases.

346

At Woodslee, future corn yield was also predicted to be significantly lower when grown

347 in monoculture (CC) than in the diversified COAA rotation (Fig 3c), with trends of increased

348 yields in COAA relative to CC. Smith et al. (2013) pointed out that DNDC predicts significant

349 increases in monoculture corn yield over time due to large projected increases in heat units and

350 increases in crop water and $\mathrm{N}$ use efficiency under elevated $\mathrm{CO}_{2}$. However, improved

351 evapotranspiration (Dutta et al., 2016) or the pedo-transfer function to adjust water holding

352 capacity in response to changes in SOC was not considered in their study. Future prediction of

353 SOC stocks at Woodslee were in line with trends observed during the experimental period with

354 COAA having significantly higher SOC than CC (Fig. 3d). At the end of the simulation period

355 (2100) Woodslee SOC showed greater increase for COAA (26\%) than for CC (16\%) compared

356 to divergences between the systems in 2015 (Fig 3d). Both COAA and CC regressions showed

357 positive trends in SOC stock, with larger increases over time predicted for COAA (Table 3). 
Results obtained for the RCP8.5 scenario (assuming high concentration of $\mathrm{CO}_{2}$ of 850

ppm, Table S5), showed no distinct difference in corn yield and SOC stock from RCP4.5 at

Elora (Figs. 3 and S4, Tables 3 and S6). In Woodslee, scenario RCP8.5 showed a slight increase

361 in corn yield of $6.5 \%$ for $\mathrm{CC}$ and COAA comparing to RCP4.5, and there was no clear difference in SOC stock (+ $0.6 \%$ in CC and $+2.1 \%$ in COAA) (Figs 3 and S4, Tables 3 and S6). The crop trend confirmed previous modelling results using a different long-term trial in

364 Woodslee where the RCP8.5 corn yield was higher by 5.4\% than the RCP 4.5 (He et al., 2017).

365 This growth in corn yield under future climate scenarios can be explained by the benefits from 366 higher temperature and $\mathrm{CO}_{2}$ fertilization effect on $\mathrm{C}_{4}$ crops (Denger, 2015; He et al., 2017). Crop 367 water, and $\mathrm{N}$ efficiency increases in DNDC under elevated $\mathrm{CO}_{2}$ in accordance with recent Free368 Air $\mathrm{CO}_{2}$ Enrichment studies (Smith et al., 2013).

\section{Conclusion}

371 The DNDC model was modified and evaluated using observed crop yields and climatic

372 parameters to improve yield estimates in diversified rotations. After revision, the DNDC

373 prediction of corn yield and SOC stock was more accurate in all cropping systems. The corn

374 rotations with winter wheat $(\mathrm{CCSW}, \mathrm{CCSW}+\mathrm{Rc})$, or alfalfa (CCAA) in Elora or oats and alfalfa

375 (COAA) in Woodslee generated greater corn yields and higher SOC stock than CC. Future 376 scenarios for Elora showed intermediate trends in increased corn yield in CCSW, CCSW+Rc and 377 CCAA, but there was no predicted increase for CC or CCSS rotation. SOC stock also increased 378 under diversified rotations, but projections for CC and CCSS indicated negative trends in SOC 379 stock. At Woodslee, future scenarios for corn yield and SOC stock were positive both for CC and 
COAA; however, the increase in corn yield and SOC stock under the COAA rotation was considerably greater than under CC. Increases in corn yield for RCP8.5 in relation to RCP4.5 were predicted for Woodslee due to the positive influence of increased atmospheric $\mathrm{CO}_{2}$. This study indicates that corn yields and SOC content under diversified rotations will be more resilient and could increase under the impacts of future climate change in comparison to $\mathrm{CC}$ or CCSS rotations, primarily due to the mitigation of crop water stress.

\section{Acknowledgements}

Funding for this research was provided by the New Directions program, Ontario Ministry of Agriculture, Food and Rural Affairs (OMAFRA). Additional funding was received from the Natural Science and Engineering Research Council, Discovery grant program.

\section{References}

Abalos, D., W.N. Smith, B.B. Grant, C.F. Drury, S. MacKell, and C. Wagner-Riddle. 2016. Scenario analysis of fertilizer management practices for $\mathrm{N}_{2} \mathrm{O}$ mitigation from corn systems in Canada. Sci. Total Environ. 573: 356-365.

Bauböck, R. 2014. Simulating the yields of bioenergy and food crops with the crop modeling software BioSTAR: the carbon-based growth engine and the BioSTAR ET0 method. Environ. Sci. Eur. 26: 1-9.doi:10.1186/2190-4715-26-1.

Bolinder M.A., H.H. Janzen, E.G. Gregorich, D.A. Angers a, A.J. VandenBygaart. 2007. An approach for estimating net primary productivity and annual carbon inputs to soil for common agricultural crops in Canada. Agric. Ecosyst. Environ. 118: 29-42 
Bolton, E. F., V.A. Dirks, and M.M. Mcllonnell. 1982. The effect of drainage, rotation and fertilizer on corn yield, plant height, leaf nutrient composition and physical properties of Brookston clay soil in southwestern Ontario. Can. J. Soil Sci. 62:297-309.

Brilli L, L. Bechini, M. Bindi, M. Carozzi, D.Cavalli, R. Conant, C.D. Dorich, L. Doro, F. Ehrhardt, R. Farina, R. Ferrise, N. Fitton, R. Francaviglia, P. Grace, I. Iocola, K. Klumpp, J. Léonard, R.Martin, R.S. Massad, S. Recous, G. Seddaiu, J. Sharp, P. Smith, W.N. Smith, J.F. Soussana and G.L. Bellocchi. 2017. Review and analysis of strengths and weaknesses of agroecosystem models in representing $\mathrm{C}$ and $\mathrm{N}$ fluxes. Sci. Total Environ. 598, 445-470.

Congreves, K. A., B. B. Grant, B. Dutta, W. N. Smith, M. H. Chantigny, P. Rochette, and R. L. Desjardins. 2016. Predicting ammonia volatilization after field application of swine slurry: DNDC model development. Agric. Ecosyst. Environ. 219: 179-189.

Congreves, K.A., A. Hayes, E. A. Verhallen, and L.L. Van Eerd. 2015. Long-term impact of tillage and crop rotation on soil health at four temperate agroecosystems. Soil Till. Res.152: $17-28$.

Deen, B. 2017. Elora crop rotation trial documentation (1981-2015). Unpublished data.

Degener, J.F. 2015. Atmospheric $\mathrm{CO}_{2}$ fertilization effects on biomass yields of 10 crops in northern Germany. Front. Environ.Sci.3:48. doi: 10.3389/fenvs.2015.00048.

Drury, C. F., X.M.Yang, W.D., Reynolds, and N.B. McLaughlin. 2008. Nitrous oxide and carbon dioxide emissions from monoculture and rotational cropping of corn, soybean and winter wheat. Can. J. Soil Sci. 88: 163-174.

Drury, C.F, X.M. Yang, W.D. Reynolds, and C.S. Tan. 2004. Influence of crop rotation and aggregate size on carbon dioxide production and denitrification. Soil Till. Res. 79: 87-100. 
424 Drury, C.F., T. O. Oloya, D. J. McKenney, E. G. Gregorich, C. S. Tan, and C. L. van Luyk. 1998. Long-Term effects of fertilization and rotation on denitrification and soil carbon. Soil Sci. Soc. Am. J. 62:1572-1579.

427 Drury, C. F. and C.S. Tan. 1995. Long-term (35 years) effects of fertilization, rotation and weather on corn yields. Can. J. Plant Sci. 75: 355-362.

Dutta, B., B. B. Grant, K. A. Congreves, W.N. Smith, C.Wagner-Riddle, A. C. VanderZaag, M. Tenuta, and R. L. Desjardins. 2017. Characterising effects of management practices, snow cover, and soil texture on soil temperature: Model development in DNDC." Biosystems Engineering. In press.

Dutta, B., W. N. Smith, B. B. Grant, E.Pattey, R. L. Desjardins, and C. Li. 2016a. Model development in DNDC for the prediction of evapotranspiration and water use in temperate field cropping systems. Environ. Modell. Softw. 80: 9-25.

Dutta, B., K. A. Congreves, W. N. Smith, B. B. Grant, P. Rochette, M. H. Chantigny, and R. L. Desjardins. 2016b. Improving DNDC model to estimate ammonia loss from urea fertilizer application in temperate agroecosystems. Nutri. Cycl. Agroecosyst.: 275-292.

Ellert, B.H., H.H. Janzen, A.J. Vander Bygaard and E. Bremmner. 2008. Measuring change in soil organic carbon storage. In: M.R. Carter and E.G. Gregorich, editors, Soil sampling and methods of analysis. 2nd ed. CRC Press Taylor \& Francis Group 6000 Broken Sound Parkway NW, Suite 300 Boca Raton, FL. p. 25-38.

Ehrhardt, F., J.F.Soussana, G. Bellocchi, P. Grace, R. McAuliffe, R., S. Recous, R. Sándor, P. Smith, V. Snow, M.D.A. Migliorati, B. Basso, A. Bhatia, L. Brilli, J. Doltra, C.D. Dorich, L. Doro, N. Fitton, S.J. Giacomini, B. Grant, M.T. Harrison, S.K. Jones, M. Kirschbaum, Klumpp, P. Laville, J.Léonard, M. Liebig, M. Lieffering, R.Martin, R.S.Massad, E. Meier, L. 
Merbold, A.D. Moore, V. Myrgiotis, P. Newton, E.Pattey, S.Rolinski, J.Sharp, W.N.Smith, L.Wu, and Q.Zhang. 2017. Assessing uncertainties in crop and pasture ensemble model simulations of productivity and $\mathrm{N}_{2} \mathrm{O}$ emissions. Glob Change Biol. Accepted Author Manuscript. doi:10.1111/gcb.13965Environment Canada. 2017. Environment Canada,

Meteorological Services of Canada, 4905 Dufferin Street, Downsview, Ontario M3H 5T4.

Farahbakhshazad, N., D.L. Dinnes, C.S. Li, D.B. Jaynes, and W.Salas. 2008. Modeling biogeochemical impacts of alternative management practices for a row-crop field in Iowa. Agric. Ecosyst. Environ. 123: 30-48.

Franzluebbers, A.J., F.M. Hons, and D.A. Zuberer, 1994. Long-term changes in soil carbon and nitrogen pools in wheat management systems. Soil Sci. Soc. Am. J. 58: 1639-1645.

Gaudin, A.C.M., T.N. Tolhurst, A.P. Ker AP, K. Janovicek, C.Tortora, and R.C. Martin. 2015. Increasing Crop Diversity Mitigates Weather Variations and Improves Yield Stability. PLoS ONE 10 (2): e0113261. doi: 10.1371/journal.pone.0113261.

Gaudin, A.C.M., S. Westra, C.E.S. Loucks, K. Janovicek, R.C. Martin and W. Deen. 2013. Improving resilience of northern field crop systems using inter-seeded red clover: a review. Agronomy 2013, 148-180; doi:10.3390/agronomy3010148.

Grant, BB., W.N.Smith, C.A. Campbell, R.L. Desjardins, R.L. Lemke, R. Kröbel, B.G. McConkey, E.G. Smith, and G.P. Lafond. 2016. Comparison of DayCent and DNDC Models: Case Studies Using Data from Long-Term Experiments on the Canadian Prairies. In: S. Del Grosso, L. Ahuja and W. Parton, editors. Synthesis and Modeling of Greenhouse Gas Emissions and Carbon Storage in Agricultural and Forest Systems to Guide Mitigation and Adaptation. Advances in Agricultural Systems Modeling 6. ASA, CSSA, SSSA. 21-58. doi:10.2134/advagricsystmodel6.2013.0035. 
He, W., J.Y. Yang, C.F. Drury, W.N. Smith, B.B. Grant and P. He. 2017. Estimating the impacts of climate change on crop yields and $\mathrm{N}_{2} \mathrm{O}$ emissions for conventional and no-tillage in Southwestern Ontario. Agri. Systems, http://dx.doi.org/10.1016/j.agsy.2017.01.025.

IPCC, 2014. Climate Change: Synthesis Report. Contribution of Working Groups I, II and III to the Fifth Assessment Report of the Intergovernmental Panel on Climate Change [Core Writing Team, R.K. Pachauri and L.A. Meyer (eds.)]. IPCC, Geneva, Switzerland.

IPCC, 2007. Fourth Assessment Report: Climate Change 2007. https://www.ipcc.ch/publications_and_data/ar4/wg1/en/spmsspm-projections-of.html (accessed 15 June 2017).

Janzen, H.H., K. Beauchemin Y. Bruinsma and E.G. Smith.2003. The fate of nitrogen in agroecosystems: An illustration using Canadian estimates. Nutr. Cycl. Agroecosys. 67:85102.

Karlen D.L., C.A. Cambardella, J.L. Kovar, and T.S. Colvin. 2013. Soil quality response to longterm tillage and crop rotation practices. Soil Till. Res. 133: 54-64.

Kröbel, R., W.N. Smith, B.B. Grant, R.L. Desjardins, C.A. Campbell, N.Tremblay, C.S. Li, R.P. Zentner, and B.G. McConkey. 2011. Development and evaluation of a new Canadian spring wheat sub-model for DNDC. Can. J. Soil Sci. 91: 503:520.

Li, C., W. Salas, Z. Ruihong, C. Krauter, A.Rotz, and F. Mitloehner. 2012. Manure-DNDC: a biogeochemical process model for quantifying greenhouse gas and ammonia emissions from livestock manure systems. Nutri. Cycl. Agroecosyst. 93: 163-200.

Li, C., J. F. Aber, F. Stange, K. Butterbach-Bahl, and H. Papen. 2000. A process-oriented model of $\mathrm{N}_{2} \mathrm{O}$ and $\mathrm{NO}$ emissions from forest soils: 1. Model development. J. Geophys. Res. 105:43694384. doi:10.1029/1999JD900949 
Liebman, M., M.J. Helmers, L.A. Schulte and C. A. Chase. 2013. Using biodiversity to link agricultural productivity with environmental quality: Results from three field experiments in Iowa. Renewable Agr. Food Syst. 28: 115-128 doi:10.1017/S1742170512000300

Liu, S., Yang, J. Y., Drury, C. F., Liu, H. L. and Reynolds, W. D. 2014. Simulating maize (Zea mays L.) growth and yield, soil nitrogen concentration, and soil water content for a long-term cropping experiment in Ontario, Canada. Can. J. Soil Sci. 94: 435-452.

Liu, H.L., J. Y. Yang, C. F. Drury, W. D. Reynolds, C. S. Tan, Y. L. Bai, P. He, J. Jin, and G. Hoogenboom. 2010. Using the DSSAT-CERES-Maize model to simulate crop yield and nitrogen cycling in fields under long-term continuous maize production. Nutr. Cycl. Agroecosyst. 89: 313-328.

Meyer-Aurich A., K. Janovicek, W. Deen, and A. Weersink. 2006a. Impact of tillage and rotation on yield and economic performance in corn-based cropping systems. Agron. J. 98:1204-1212.

Meyer-Aurich A, A. Weersink, K. Janovicek, and B. Deen. 2006b. Cost efficient rotation and tillage options to sequester carbon and mitigate GHG emissions from agriculture in Eastern Canada. Agr. Ecosys. Environ.117:119-127.

Munkholm L.J., R.J. Heck, and B. Deen. 2013. Long-term rotation and tillage effects on soil structure and crop yield. Soil Till Res. 127:85-91 .DOI: 10.1016/j.still.2012.02.007

Nash, J. E., and J.V. Sutcliffe. 1970. River flow forecasting through conceptual models, Part I A discussion of principles. J. Hydrol. 10:282-290.

Ramnarine R., R. P. Voroney, C. Wagner-Riddle, and K. E. Dunfield. 2014. Conventional and no-tillage effects on the distribution of crop residues and light fraction organic matter. Soil Sci. Soc. Am. J. 79:74-80. 
516 Reynolds, W. D., C.F. Drury, X.M. Yang, C.S. Tan, and J.Y. Yang. 2014. Impacts of 48 years of 517 consistent cropping, fertilization and land management on the physical quality of a clay loam 518 soil. Can. J. Soil Sci. 94: 403-419.

519 Saxton, K.E., and W. Rawls. 2009. Soil water characteristics hydraulic properties calculator. 520 http://hrsl.ba.ars.usda.gov/soilwater/Index.htm (accessed 15 May 2017).

521 Saxton, K.E. and W.J. Rawls. 2006. Soil water characteristic estimates by texture and organic 522 matter for hydrologic solutions. Soil Sci. Soc.Am. J. 70: 1569-1578.

523 Selles, F. and R.P. Zentner. 1993. Spring wheat yield trends in long-term fertility trials. Can. J. $524 \quad$ Plant Sci. 73: 83-92.

525 Smith,W.N., B.B. Grant, R.L. Desjardins, R. Kroebel, C. Li, B. Qiana, D.E. Worth, B.G.

526 McConkey, and C.F. Drury. 2013. Assessing the effects of climate change on crop production 527 and GHG emissions in Canada. Agric. Ecosyst. Environ. 179: 139- 150.

528 Smith,W.N., B.B. Grant, C.A. Campbell, B.G. McConkey, R.L. Desjardins, R. Kröbel, and S.S. 529 Malhi. 2012. Crop residue removal effects on soil carbon: Measured and inter-model 530 comparisons. Agric. Ecosyst. Environ.161: 27- 38.

531 Smith, W. N., B.B. Grant, R.L.Desjardins, P. Rochette, C.F. Drury, and C. Li. 2008. Evaluation 532 of two process-based models to estimate soil N2O emissions in Eastern Canada. Can. J. Soil 533 Sci. 88: 251-260.

534 Smith, W. N., R.L. Desjardins, B. Grant, C.Li, R.Lemke, P. Rochette, M.D. Corre, and D.

535 Pennock. 2002. Testing the DNDC model using $\mathrm{N}_{2} \mathrm{O}$ emissions at two experimental sites in 536 Canada. Can. J. Soil Sci. 82: 365-374.

537 Soper, D.S. 2017. Significance of the difference between two slopes calculator [Software]. 538 Available from http://www.danielsoper.com/statcalc (accessed 15 Jun. 2017). 
539 Tan C.S., C.F. Drury, W.D. Reynolds, P.H. Groenevelt, and H. Dadfar. 2002. Water and nitrate $540 \quad$ loss through tiles under a clay loam soil in Ontario after 42 years of consistent fertilization 541 and crop rotation. Agric. Ecosyst. Environ 93: 121-130.

542 Van Vuuren, D.P., J. Edmonds, M. Kainuma, K. Riahi, A.Thomson, K. Hibbard, G.C. Hurtt, T. 543 ram, V. Krey, J. Lamarque, T. Masui, M. Meinshausen, N. Nakicenovic, S.J. Smith, and S.K. 544 Rose. 2011. The representative concentration pathways: an overview. Clim.Chang. 109: 554531.

546 Wanniarachchi S.D., R. P. Voroney, T. J. Vyn, R. P. Beyaert, and A. F. MacKenzie. 1999. Tillage 547 effects on the dynamics of total and corn-residue derived soil organic matter in two southern $548 \quad$ Ontario soils. Can. J. Soil Sci. 89: 473-480.

549 Yan, W., L.A. Hunt. 1999. An equation for modelling the temperature response of plants using 550 only the cardinal temperatures. Ann. Bot. 84, 607-614.

551 doi:http://dx.doi.org/10.1006/anbo.1999.0955.

552 Yang X. M., C. F. Drury, M. M. Wander and B. D. Kay. 2008. Evaluating the effect of tillage on 553 carbon sequestration using the minimum detectable difference concept. Pedosphere 18: 421$554 \quad 430$.

555 Zhang Y, and H. Niu. 2016. The development of the DNDC plant growth sub-model and the 556 application of DNDC in agriculture: A review. Agric. Ecosys. Environ. 230: 271-282. 
557 Table 1. Statistical evaluation of observed and DNDC-simulated corn yields for Elora and

558 Woodslee before and after model revision. Average corn yields over 35 and 57 years are shown

559 for Elora (1981-2015) and Woodslee (1959-2015), respectively, for cropping systems: $\mathrm{CC}=$

560 continuous corn, CCSS = corn-corn-soybean-soybean, CCSW = corn-corn-soybean-winter

561 wheat, $\mathrm{CCSW}+\mathrm{Rc}=$ corn-corn-soybean-winter wheat with red clover as a cover crop after

562 wheat, CCAA = corn-corn-alfalfa-alfalfa, and COAA = corn-oats-alfalfa-alfalfa. RMSE = root

563 mean squared error, MAPE = mean absolute percentage error, $R^{2}=$ coefficient of determination

564 for regression between observed and modelled yields, and EF = model efficiency.

\begin{tabular}{|c|c|c|c|c|c|c|c|c|c|c|c|}
\hline \multirow{3}{*}{$\begin{array}{l}\text { Site/ } \\
\text { System }\end{array}$} & \multicolumn{3}{|c|}{ Average corn yield } & \multirow{2}{*}{\multicolumn{2}{|c|}{ RMSE }} & \multirow{2}{*}{\multicolumn{2}{|c|}{ MAPE }} & \multirow{2}{*}{\multicolumn{2}{|c|}{$R^{2}$}} & \multirow{2}{*}{\multicolumn{2}{|c|}{$\mathrm{EF}$}} \\
\hline & \multirow[t]{2}{*}{ Obs. } & \multicolumn{2}{|c|}{ Model } & & & & & & & & \\
\hline & & before & after & before & after & before & after & before & after & before & after \\
\hline Elora & \multicolumn{5}{|c|}{ 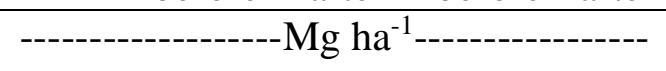 } & \multicolumn{2}{|c|}{------\% \%----- } & & & & \\
\hline $\mathrm{CC}$ & $\begin{array}{l}8.57 \\
(1.69)\end{array}$ & $\begin{array}{l}8.39 \\
(1.49)\end{array}$ & $\begin{array}{l}8.49 \\
(1.66)\end{array}$ & 1.13 & 1.17 & 11.8 & 11.6 & 0.58 & 0.56 & 0.54 & 0.51 \\
\hline CCSS & $\begin{array}{l}8.69 \\
(1.81)\end{array}$ & $\begin{array}{l}8.41 \\
(1.39)\end{array}$ & $\begin{array}{l}8.46 \\
(1.26)\end{array}$ & 1.47 & 1.42 & 15.5 & 14.6 & 0.37 & 0.38 & 0.32 & 0.37 \\
\hline CCSW & $\begin{array}{l}8.77 \\
(1.79)\end{array}$ & $\begin{array}{l}9.05 \\
(1.38)\end{array}$ & $\begin{array}{l}9.02 \\
(1.43)\end{array}$ & 1.28 & 1.19 & 13.4 & 12.6 & 0.50 & 0.56 & 0.46 & 0.54 \\
\hline $\mathrm{CCSW}+\mathrm{Rc}$ & $\begin{array}{l}9.21 \\
(1.92)\end{array}$ & $\begin{array}{l}8.55 \\
(1.24)\end{array}$ & $\begin{array}{l}9.40 \\
(1.36)\end{array}$ & 1.60 & 1.35 & 15.4 & 12.2 & 0.40 & 0.50 & 0.28 & 0.49 \\
\hline CCAA & $\begin{array}{l}9.21 \\
(1.86)\end{array}$ & $\begin{array}{l}8.71 \\
(1.29)\end{array}$ & $\begin{array}{l}8.78 \\
(1.66)\end{array}$ & 1.46 & 1.41 & 13.5 & 10.9 & 0.44 & 0.50 & 0.36 & 0.40 \\
\hline \multicolumn{12}{|l|}{ Woodslee } \\
\hline $\mathrm{CC}$ & $\begin{array}{l}5.98 \\
(1.74)\end{array}$ & $\begin{array}{l}6.34 \\
(1.17)\end{array}$ & $\begin{array}{l}6.29 \\
(1.36)\end{array}$ & 1.39 & 1.40 & 25.8 & 24.7 & 0.40 & 0.40 & 0.35 & 0.35 \\
\hline COAA & $\begin{array}{l}8.22 \\
(2.00)\end{array}$ & $\begin{array}{l}6.54 \\
(1.29)\end{array}$ & $\begin{array}{l}7.65 \\
(1.79)\end{array}$ & 2.57 & 1.76 & 24.0 & 16.6 & 0.20 & 0.38 & -0.50 & 0.21 \\
\hline
\end{tabular}

565

566

567

568

569

570

571

572

573

574 
575 Table 2. Observed and predicted mean soil carbon stock in 0-0.2 m layer at Elora and Woodslee 576 with standard error of mean shown in brackets. $n=$ number of samples.

577

\begin{tabular}{|c|c|c|c|c|}
\hline \multirow[b]{2}{*}{ Location } & \multirow{2}{*}{$\begin{array}{l}\text { Cropping } \\
\text { system }\end{array}$} & & Observed & DNDC \\
\hline & & $\mathrm{n}$ & 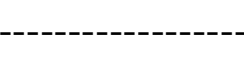 & $\mathrm{ha}^{-1}$ \\
\hline \multirow{5}{*}{ Elora } & $\mathrm{CC}$ & 5 & $54.13(1.06)$ & $53.74(0.39)$ \\
\hline & CCSS & 3 & $53.46(0.515)$ & $52.97(0.26)$ \\
\hline & CCSW & 3 & $58.60(1.61)$ & $59.93(2.84)$ \\
\hline & $\mathrm{CCSW}+\mathrm{Rc}$ & 2 & $58.40(2.04)$ & $61.17(1.45)$ \\
\hline & CCAA & 2 & $58.26(0.55)$ & $55.81(1.26)$ \\
\hline & $\mathrm{CC}$ & 3 & $52.02(1.31)$ & $51.36(0.248)$ \\
\hline Woodslee & COAA & 3 & $62.96(1.03)$ & $61.09(0.566)$ \\
\hline
\end{tabular}


579 Table 3. Regression analysis of predicted corn yield and 0-0.2 $\mathrm{m}$ soil organic carbon stock under 580 representative concentration pathway (RCP) scenario RCP 4.5 for the 2016-2100 period at Elora 581 and Woodslee. Results are shown for CC $=$ continuous corn; CCSS $=$ corn-corn-soybean-

582 soybean, $\mathrm{CCSW}=$ corn-corn-soybean-winter wheat, $\mathrm{CCSW}+\mathrm{Rc}=$ corn-corn-soybean-winter 583 wheat + red clover, CCAA = corn-corn-alfalfa- alfalfa, COAA = corn-oats-alfalfa-alfalfa. Linear 584 regression slopes followed by different letters for each site indicate significant trends over time 585 among cropping systems.

\begin{tabular}{|c|c|c|c|c|c|c|c|}
\hline Site & Factor & Rotation & $R^{2}$ & slope & St error & t value & $P$-value \\
\hline \multirow{10}{*}{ Elora } & \multirow{5}{*}{$\begin{array}{l}\text { Corn } \\
\text { Yield }\end{array}$} & $\mathrm{CC}$ & 0.01 & $4.38 c$ & 4.73 & 0.93 & 0.36 \\
\hline & & CCSS & 0.00 & $-0.67 c$ & 4.67 & -0.14 & 0.89 \\
\hline & & CCSW & 0.66 & $36.61 b$ & 2.41 & 15.19 & 0.00 \\
\hline & & $\mathrm{CCSW}+\mathrm{Rc}$ & 0.67 & $36.98 b$ & 2.39 & 15.46 & 0.00 \\
\hline & & CCAA & 0.59 & $46.50 \mathrm{a}$ & 3.52 & 13.22 & 0.00 \\
\hline & \multirow{5}{*}{ SOC } & $\mathrm{CC}$ & 0.32 & $-11.78 \mathrm{e}$ & 1.56 & -7.54 & 0.00 \\
\hline & & CCSS & 0.90 & $-35.38 d$ & 1.06 & -33.46 & 0.00 \\
\hline & & CCSW & 0.97 & $41.74 c$ & 0.72 & 58.14 & 0.00 \\
\hline & & $\mathrm{CCSW}+\mathrm{Rc}$ & 0.99 & $108.5 \mathrm{a}$ & 0.96 & 112.7 & 0.00 \\
\hline & & CCAA & 0.95 & $101.1 \mathrm{~b}$ & 2.04 & 49.5 & 0.00 \\
\hline \multirow{4}{*}{ Woodslee } & Corn & $\mathrm{CC}$ & 0.06 & $9.53 b$ & 3.15 & 3.02 & 0.00 \\
\hline & yield & COAA & 0.23 & $23.72 \mathrm{a}$ & 3.50 & 6.64 & 0.00 \\
\hline & \multirow{2}{*}{ SOC } & $\mathrm{CC}$ & 0.32 & $4.91 b$ & 0.60 & 8.20 & 0.00 \\
\hline & & COAA & 0.98 & $218.64 a$ & 1.91 & 114.6 & 0.00 \\
\hline
\end{tabular}




\section{Figure captions:}

589

590

591

592

593

594

595

596

597

598

599

600

601

602

603

604

605

606

607

Fig. 1. Comparison of simulated and observed corn yield from 1981 to 2015 under five cropping systems at Elora for: a) continuous corn (CC), b) corn-corn-soybean-soybean (CCSS), c) corncorn-soybean-winter wheat (CCSW), d) corn-corn-soybean-winter wheat + red clover $(\mathrm{CCSW}+\mathrm{Rc})$ and e) corn-corn-alfalfa-alfalfa (CCAA). Simulated values were obtained with the DNDC model before and after model revision to account for long-term effects of diversified rotations on soil conditions.

Fig. 2. Comparison of simulated and observed corn yield from 1959 to 2015 at Woodslee for: a) continuous corn $(\mathrm{CC})$, and b) corn-oats-alfalfa-alfalfa rotation (COAA). Simulated values were obtained with the DNDC model before and after revision to account for long-term effects of diversified rotations on soil conditions.

Fig. 3. Predictions of corn yield (a. and b.) and 0-0.2 m SOC stock (c. and d.) under representative concentration pathway (RCP) scenario RCP 4.5 over 2016 to 2100 at Elora (a. and c.) and Woodslee (b. and d.) for various cropping systems. Predictions were averaged over selected periods starting in 2016 with error bars representing standard error of means $(n=25$ for 2016-2040, and $\mathrm{n}=20$ for other periods). CC = continuous corn; CCSS = corn-corn-soybeansoybean, CCSW = corn-corn-soybean-winter wheat, CCSW+Rc = corn-corn-soybean-winter wheat + red clover, CCAA $=$ corn-corn-alfalfa- alfalfa, COAA = corn-oats-alfalfa-alfalfa. 


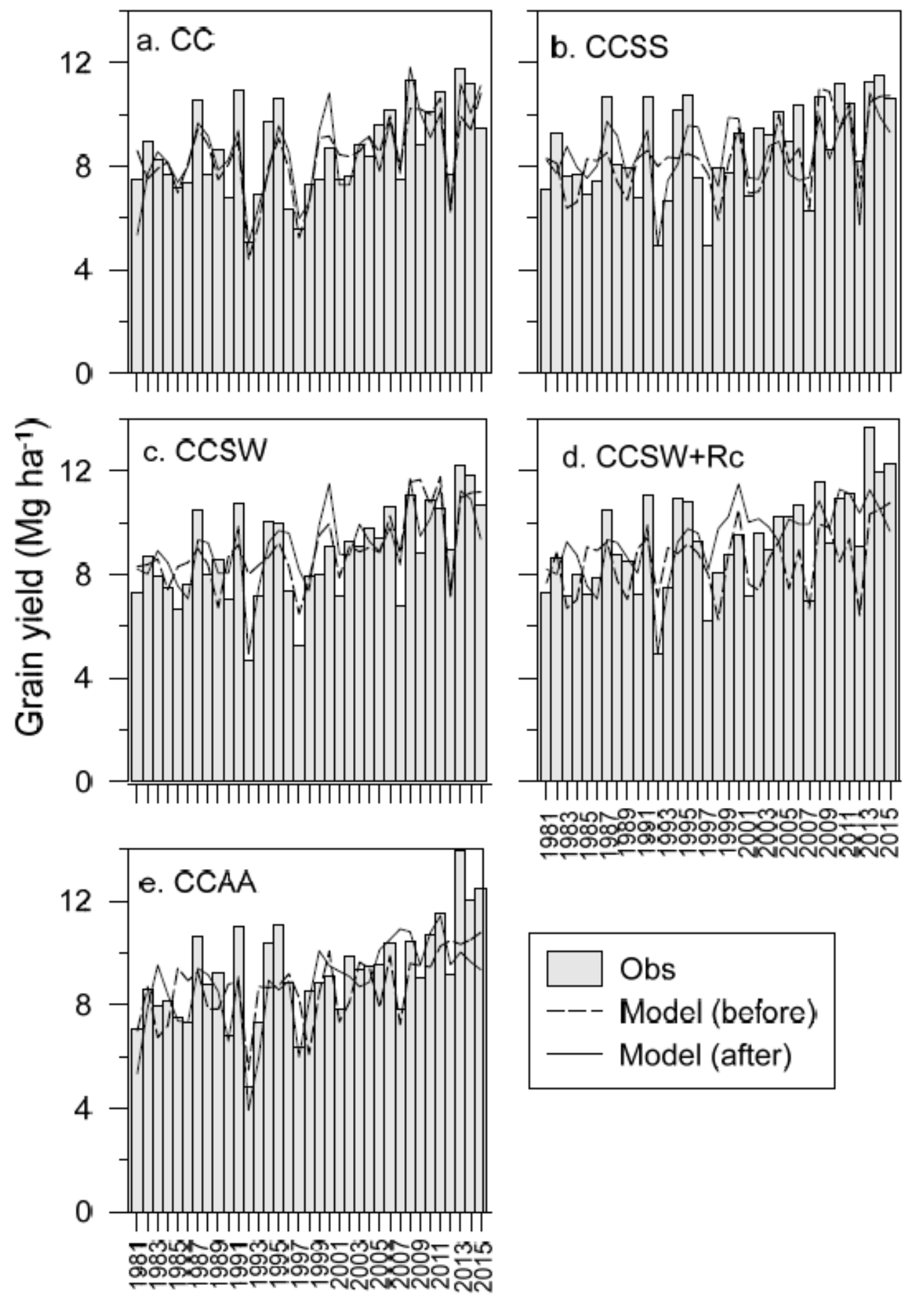

609

$610 \quad$ Fig 1 


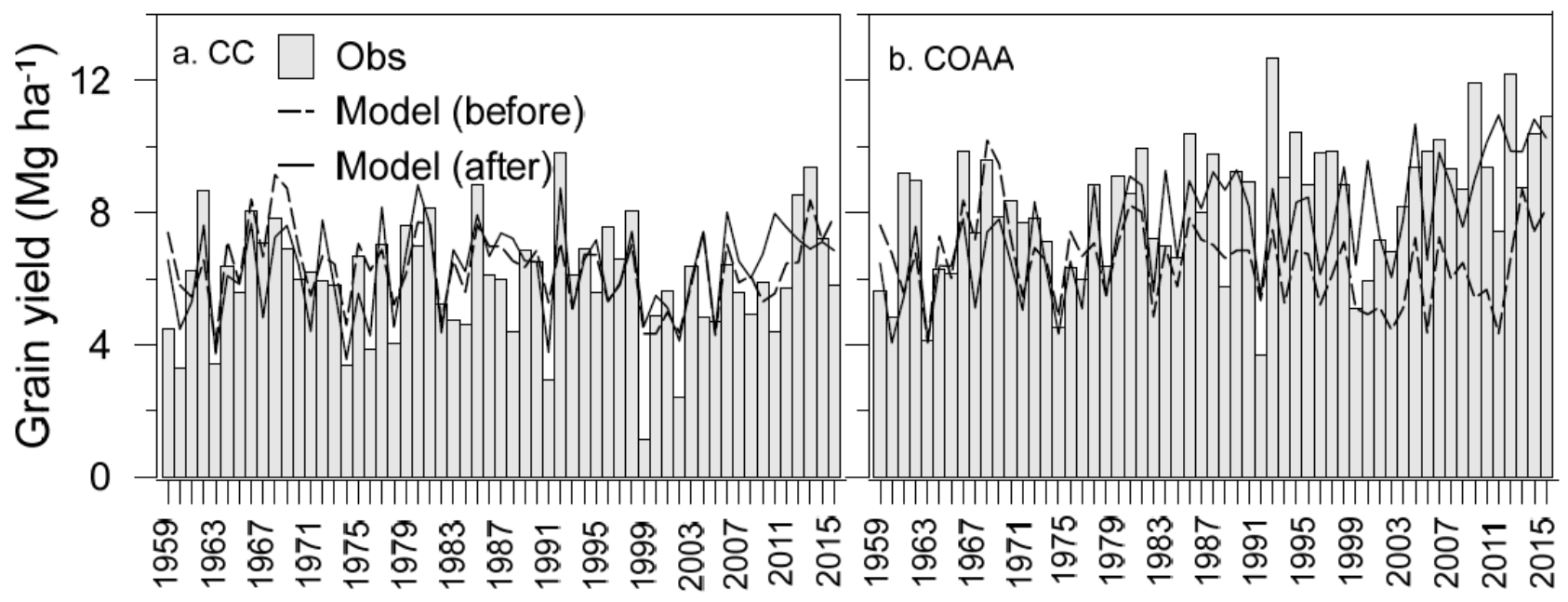

611

$612 \quad$ Fig 2 
Elora

$\square \mathrm{CC} \quad \mathrm{CCSS} \triangle \mathrm{CCSW}$ - CCSW+Rc 目 CCAA
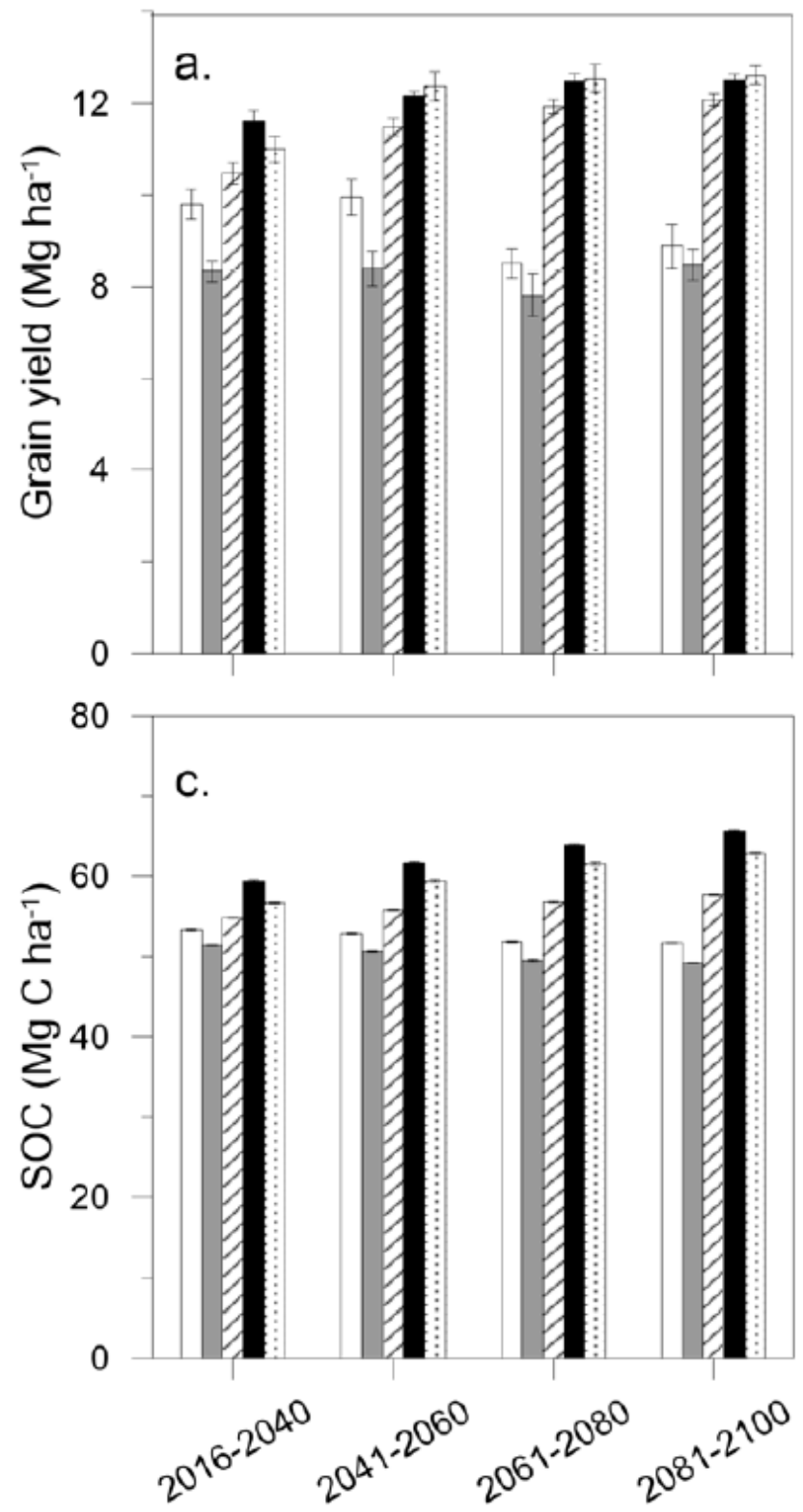

Woodslee

$\square \mathrm{CC} \quad \square \mathrm{COAA}$

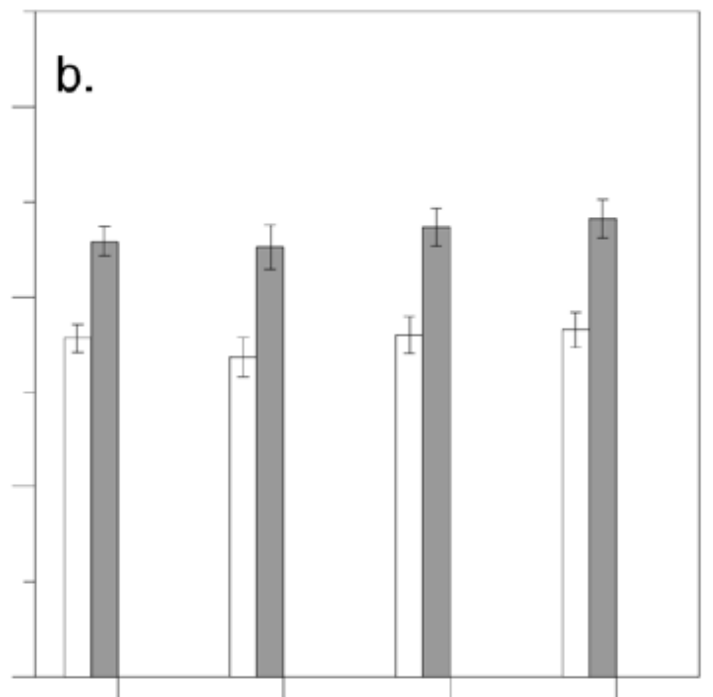

d.

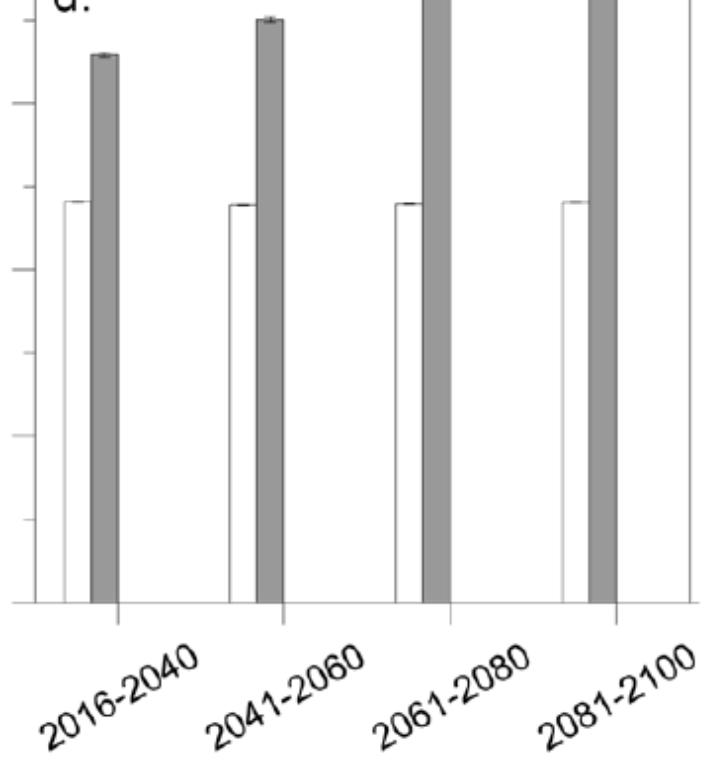

613

Fig 3

615 


\section{Supplemental Material}

617 Long-term trends in corn yields and soil carbon under diversified crop rotations

618 Marek Jarecki ${ }^{1}$, Brian Grant ${ }^{2}$, Ward Smith $^{2}$, Bill Deen ${ }^{3}$, Craig Drury ${ }^{4}$, Andrew VanderZaag ${ }^{2}$,

619 Budong Qian ${ }^{2}$, Jingyi Yang ${ }^{4}$ and Claudia Wagner-Riddle ${ }^{1}$

$620{ }^{1}$ School of Environmental Sciences, University of Guelph, Guelph, ON, Canada; ${ }^{2}$ Ottawa

621 Research and Development Centre, Agriculture and Agri-Food Canada, Ottawa, ON, Canada;

$622{ }^{3}$ Department of Plant Agriculture, University of Guelph, Guelph, ON, Canada; ${ }^{4}$ Harrow

623 Research and Development Centre, Agriculture and Agri-Food Canada, Harrow, ON, Canada. 
624 Table S1. Soil and crop management inputs for corn grown in monoculture and in crop rotations 625 at Elora and Woodslee, Ontario Canada.

\begin{tabular}{|c|c|c|c|c|c|c|}
\hline \multicolumn{7}{|c|}{ Soil Inputs $(0-0.20 \mathrm{~m})$} \\
\hline Site & $\mathrm{pH}$ & SOC & $\mathrm{BD}$ & $\begin{array}{c}\text { Wilting } \\
\text { point }\end{array}$ & $\begin{array}{c}\text { Field } \\
\text { capacity }\end{array}$ & $\begin{array}{c}\text { Saturated } \\
\text { Hydraulic } \\
\text { Conductivity }\end{array}$ \\
\hline & & $\mathrm{g} \mathrm{kg}^{-1}$ & $\mathrm{Mg} \mathrm{m}^{-3}$ & \multicolumn{2}{|c|}{$\% \mathrm{Vol}$} & $\mathrm{mm} \mathrm{h}^{-1}$ \\
\hline Elora & 7.3 & 170 & 1.30 & 12.8 & 31.1 & 23.8 \\
\hline Woodslee & 6.1 & 370 & 1.35 & 23.4 & 37.6 & 6.02 \\
\hline \multicolumn{7}{|c|}{ Crop management inputs } \\
\hline \multirow[b]{3}{*}{ Elora } & \multirow{2}{*}{ Planting } & \multicolumn{3}{|c|}{ Fertilizer application } & \multicolumn{2}{|c|}{ Tillage application } \\
\hline & & Starter & \multicolumn{2}{|c|}{ Side-dress } & Spring & Fall \\
\hline & May & $\begin{array}{l}\text { At planting } 8 \mathrm{~kg} \mathrm{~N} \\
\mathrm{ha}^{-1}\end{array}$ & \multicolumn{2}{|c|}{$\begin{array}{l}6^{\text {th }} \text { leaf stage } \\
140-150 \mathrm{~kg} \mathrm{~N} \mathrm{ha}^{-1}\end{array}$} & $\begin{array}{l}\text { Disc } \\
\text { before } \\
\text { planting }\end{array}$ & $\begin{array}{l}\text { Moldboard } \\
\text { plowing end of } \\
\text { Oct to mid-Nov }\end{array}$ \\
\hline Woodslee & $\begin{array}{l}\text { mid- May } \\
\text { to June }\end{array}$ & $\begin{array}{l}\text { One day before } \\
\text { planting }\end{array}$ & \multicolumn{2}{|c|}{$\begin{array}{l}6^{\text {th }} \text { leaf stage } \\
112 \mathrm{~kg} \mathrm{~N} \mathrm{ha}^{-1}\end{array}$} & $\begin{array}{l}\text { Disc } \\
\text { before } \\
\text { planting }\end{array}$ & $\begin{array}{l}\text { Moldboard } \\
\text { plowing end of } \\
\text { Oct to mid-Nov }\end{array}$ \\
\hline
\end{tabular}

626

627

628

629

630

631

632

633

634

635

636

637 
638 Table S2. Climate means for the period over which long-term cropping experiments were 639 conducted at the two sites in Ontario, Canada.

\begin{tabular}{lll}
\hline Site & Elora & Woodslee \\
\hline Period & $1981-2015$ & $1959-2015$ \\
Annual precipitation $(\mathrm{mm})$ & 1009 & 844 \\
Precipitation May-Sep $(\mathrm{mm})$ & 426 & 410 \\
Annual maximum temperature $\left({ }^{\circ} \mathrm{C}\right)$ & 11.4 & 13.9 \\
Annual minimum temperature $\left({ }^{\circ} \mathrm{C}\right)$ & 1.8 & 4.7 \\
Growing degree-days ${ }^{\dagger}$ & 1009 & 1405 \\
Solar radiation $\left(\mathrm{MJ} \mathrm{m}^{2}\right)$ & 13.4 & 13.6 \\
Wind speed $\left(\mathrm{m} \mathrm{s}^{-1}\right)$ & 4.0 & 3.4 \\
Relative humidity $(\%)$ & 81 & 75
\end{tabular}

641 minimum temperatures and subtracting base temperature $\left(10^{\circ} \mathrm{C}\right)$. When average temperature was $642<10^{\circ} \mathrm{C}$, degree day value $=0$.

643

644

645

646

647

648

649

650

651

652

653

654

655

656

657 
658 Table S3. Calibration results for DNDC model runs at the Woodslee site using the first 10 years 659 of continuous corn yield.

\begin{tabular}{|c|c|c|c|}
\hline \multicolumn{4}{|c|}{ A. Corn yield $\left(\mathrm{Mg} \mathrm{ha}^{-1}\right) 1959-1968$} \\
\hline Year & Observed Yield & Before calibration & After calibration \\
\hline 1959 & 4.46 & 5.93 & 6.57 \\
\hline 1960 & 3.30 & 4.36 & 4.48 \\
\hline 1961 & 6.23 & 5.00 & 5.31 \\
\hline 1962 & 8.69 & 4.36 & 7.62 \\
\hline 1963 & 3.24 & 3.99 & 3.72 \\
\hline 1964 & 6.37 & 4.35 & 6.10 \\
\hline 1965 & 5.59 & 5.20 & 5.83 \\
\hline 1966 & 8.07 & 4.45 & 7.68 \\
\hline 1967 & 7.08 & 6.31 & 4.83 \\
\hline 1968 & 7.81 & 5.34 & 7.27 \\
\hline Average & 6.10 & 4.93 & 5.94 \\
\hline Standard deviation & 1.90 & 0.76 & 1.36 \\
\hline \multicolumn{4}{|c|}{ B. Statistical evaluation } \\
\hline \multicolumn{2}{|c|}{ Root mean square error (RMSE, $\left.\mathrm{Mg} \mathrm{ha}^{-1}\right)$} & 2.18 & 1.16 \\
\hline \multicolumn{2}{|c|}{ Mean absolute percentage error (MAPE, \%) } & 38.0 & 16.8 \\
\hline \multicolumn{2}{|c|}{ Coefficient of determination $\left(R^{2}\right)$} & 0.02 & 0.59 \\
\hline \multicolumn{2}{|c|}{ Model efficiency (EF) } & -0.47 & 0.58 \\
\hline
\end{tabular}

660

661

662

663

664

665

666

667

668 
669 Table S4. Sources of soil organic carbon measurements per depth used to compared with DNDC

670 model outputs for the two studied sites.

671 Carbon concentration was recalculated from SOC content

\begin{tabular}{|c|c|c|c|c|c|c|}
\hline \multirow{3}{*}{$\begin{array}{l}\text { Site/year } \\
\text { Elora }\end{array}$} & \multicolumn{5}{|c|}{ Available sampling depth $(\mathrm{m})$ for each cropping } & \multirow{3}{*}{ Source } \\
\hline & \multicolumn{5}{|c|}{ systems } & \\
\hline & $\mathrm{CC}$ & CCSS & CCSW & $\mathrm{CCSW}+\mathrm{Rc}$ & CCAA & \\
\hline 1995 & $0-0.5$ & $\mathrm{NA}^{\dagger}$ & NA & NA & NA & $\begin{array}{l}\text { Wanniarachichi et al. } \\
\text { (1999) }\end{array}$ \\
\hline 1998 & $0-0.5$ & $0-0.5$ & $0-0.5$ & $0-0.5$ & NA & Deen (2017) (unpublished) \\
\hline 2000 & $0-0.5$ & $0-0.5$ & $0-0.5$ & $0-0.5$ & $0-0.5$ & Deen (2017) (unpublished) \\
\hline 2005 & $0-0.5$ & NA & NA & NA & NA & Yang et al. (2008) \\
\hline 2015 & $0-0.5$ & $0-0.5$ & $0-0.5$ & NA & $0-0.5$ & Deen (2017) (unpublished) \\
\hline Woodslee & & $\mathrm{CC}$ & & $\mathrm{CO}$ & & \\
\hline 1994 & & $0-0.5$ & & $0-0$ & & Drury et al. (1994) \\
\hline $2002 \ddagger$ & & $0-0.15$ & & $0-0$ & & Drury et al. (2004) \\
\hline 2004-2007 & & $0-0.50$ & & $0-0$ & & Reynolds et al. (2014) \\
\hline
\end{tabular}

672 \$ Not available

673

674

675

676

677

678

679

680

681

682

683 
684 Table S5. Atmospheric conditions for historical (1981-2015 for Elora; 1959-2015 for Woodslee) 685 and future projections (up to 2100) at two representative concentration pathways (RCP4.5 and $686 \mathrm{RCP} 8.5$ ) in Ontario, Canada. Historical years correspond to duration of long-term cropping 687 system trials.

\begin{tabular}{|c|c|c|c|c|c|c|c|}
\hline \multirow[b]{3}{*}{ Location } & \multirow{3}{*}{ Scenario } & \multicolumn{2}{|c|}{$\begin{array}{c}\text { Average annual } \\
\text { temperature }\end{array}$} & \multicolumn{2}{|c|}{ Annual precipitation } & \multicolumn{2}{|c|}{$\begin{array}{c}\mathrm{CO}_{2} \\
\text { concentration }\end{array}$} \\
\hline & & RCP4.5 & RCP8.5 & $\mathrm{RCP} 4.5$ & RCP8.5 & RCP4.5 & RCP8.5 \\
\hline & & \multicolumn{2}{|c|}{------------- ${ }^{\circ} \mathrm{C}-----------$} & \multicolumn{2}{|c|}{-----------'mm------------ } & \multicolumn{2}{|c|}{-------mg m³ } \\
\hline \multirow{5}{*}{ Elora } & $1981-2015$ & 6.6 & 6.6 & 1009 & 1009 & 367 & 367 \\
\hline & 2016-2040 & 8.1 & 8.6 & 1002 & 949 & 431 & 443 \\
\hline & $2041-2060$ & 9.3 & 9.7 & 1003 & 1031 & 487 & 545 \\
\hline & $2061-2080$ & 9.9 & 10.8 & 992 & 1081 & 523 & 682 \\
\hline & $2081-2100$ & 10.1 & 12.8 & 1044 & 1070 & 534 & 850 \\
\hline \multirow{5}{*}{ Woodslee } & 1959-2015 & 9.3 & 9.3 & 844 & 844 & 359 & 359 \\
\hline & 2016-2040 & 10.9 & 11.4 & 878 & 848 & 407 & 411 \\
\hline & $2041-2060$ & 12.1 & 12.5 & 857 & 947 & 462 & 493 \\
\hline & $2061-2080$ & 12.5 & 13.8 & 826 & 976 & 509 & 609 \\
\hline & $2081-2100$ & 12.8 & 15.1 & 908 & 966 & 534 & 850 \\
\hline
\end{tabular}

688

689

690

691

692

693

694

695

696

697

698

699

700

701 
702 Table S6. Regression analysis of predicted corn yield and 0-0.2 m soil organic carbon stock 703 under representative concentration pathway (RCP) scenario RCP 8.5 for the 2016-2100 period at 704 Elora and Woodslee. Results are shown for CC = continuous corn; CCSS = corn-corn-soybean705 soybean, CCSW = corn-corn-soybean-winter wheat, CCSW+Rc = corn-corn-soybean-winter 706 wheat + red clover, CCAA = corn-corn-alfalfa- alfalfa, COAA = corn-oats-alfalfa-alfalfa. Linear 707 regression slopes followed by different letters for each site indicate significant trends over time 708 among cropping systems.

\begin{tabular}{|c|c|c|c|c|c|c|c|}
\hline Site & Factor & Rotation & $R^{2}$ & Slope & St error & $t$ value & P-value \\
\hline \multirow{10}{*}{ Elora } & \multirow{5}{*}{$\begin{array}{l}\text { Corn } \\
\text { Yield }\end{array}$} & $\mathrm{CC}$ & 0.01 & $4.04 \mathrm{c}$ & 4.54 & 0.89 & 0.38 \\
\hline & & CCSS & 0.00 & $-1.52 c$ & 4.41 & -0.34 & 0.73 \\
\hline & & CCSW & 0.71 & $40.17 b$ & 2.33 & 17.24 & 0.00 \\
\hline & & $\mathrm{CCSW}+\mathrm{Rc}$ & 0.74 & $40.60 \mathrm{~b}$ & 2.20 & 18.17 & 0.00 \\
\hline & & CCAA & 0.62 & $53.13 \mathrm{a}$ & 3.81 & 13.95 & 0.00 \\
\hline & \multirow{5}{*}{ SOC } & $\mathrm{CC}$ & 0.47 & $-15.53 \mathrm{e}$ & 1.52 & -10.24 & 0.00 \\
\hline & & CCSS & 0.95 & $-39.80 \mathrm{~d}$ & 0.86 & -46.10 & 0.00 \\
\hline & & CCSW & 0.96 & $46.18 \mathrm{c}$ & 0.85 & 54.26 & 0.00 \\
\hline & & $\mathrm{CCSW}+\mathrm{Rc}$ & 0.99 & $116.6 \mathrm{a}$ & 0.98 & 118.9 & 0.00 \\
\hline & & CCAA & 0.94 & $92.47 b$ & 2.16 & 42.9 & 0.00 \\
\hline \multirow{4}{*}{ Woodslee } & Corn & $\mathrm{CC}$ & 0.17 & $16.58 \mathrm{~b}$ & 3.09 & 5.37 & 0.00 \\
\hline & yield & COAA & 0.38 & $32.10 \mathrm{a}$ & 3.49 & 9.20 & 0.00 \\
\hline & & $\mathrm{CC}$ & 0.62 & $9.30 \mathrm{~b}$ & 0.60 & 15.20 & 0.00 \\
\hline & SOC & COAA & 0.99 & $238.5 \mathrm{a}$ & 1.33 & 179.0 & 0.00 \\
\hline
\end{tabular}


714
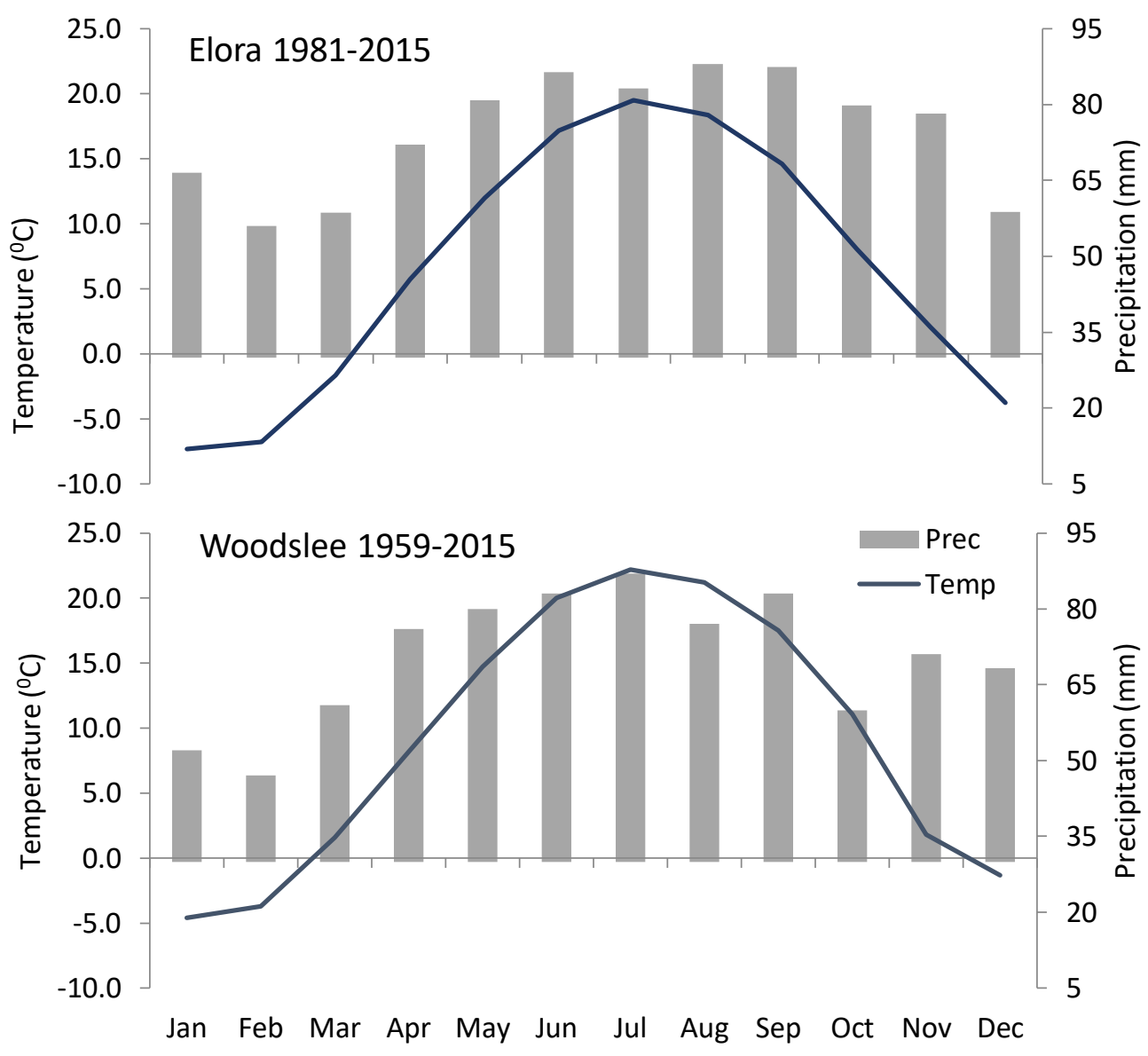

716 Fig. S1. Average monthly temperature and precipitation at two locations in Ontario, Canada, 717 over the experimental period used for modelling. 


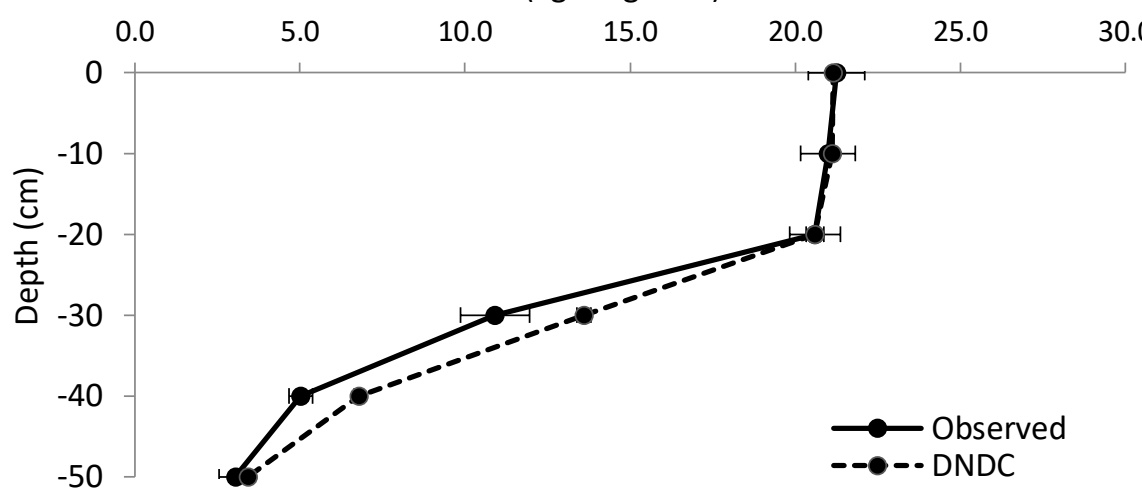

727

b) Woodslee: CC

728

729

730

731

732

733

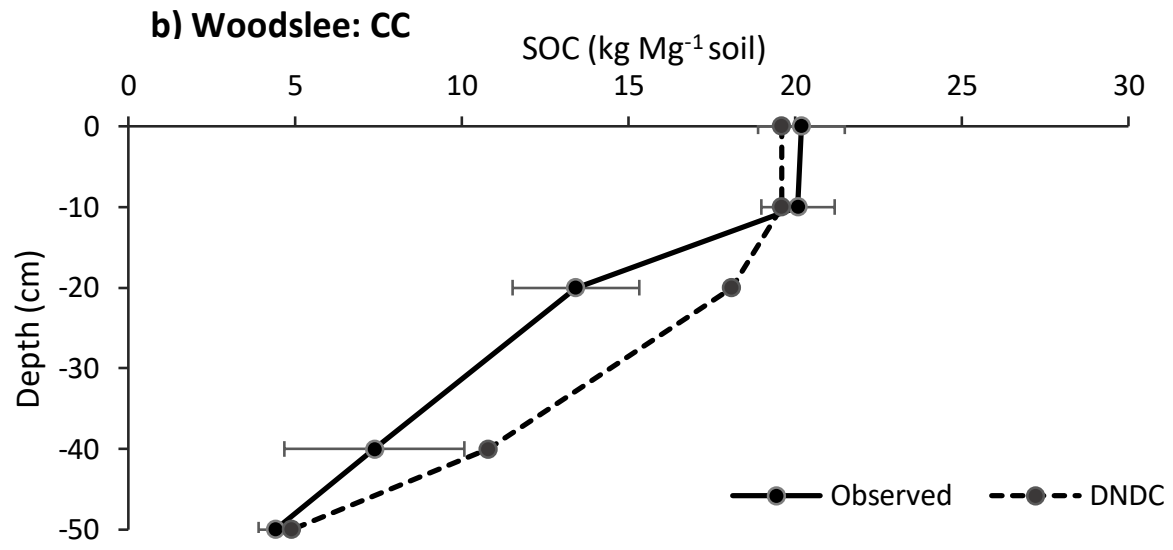

734

735

c) Woodslee: COAA

736

737

738

739

740

741

742

743

744

745

746

747

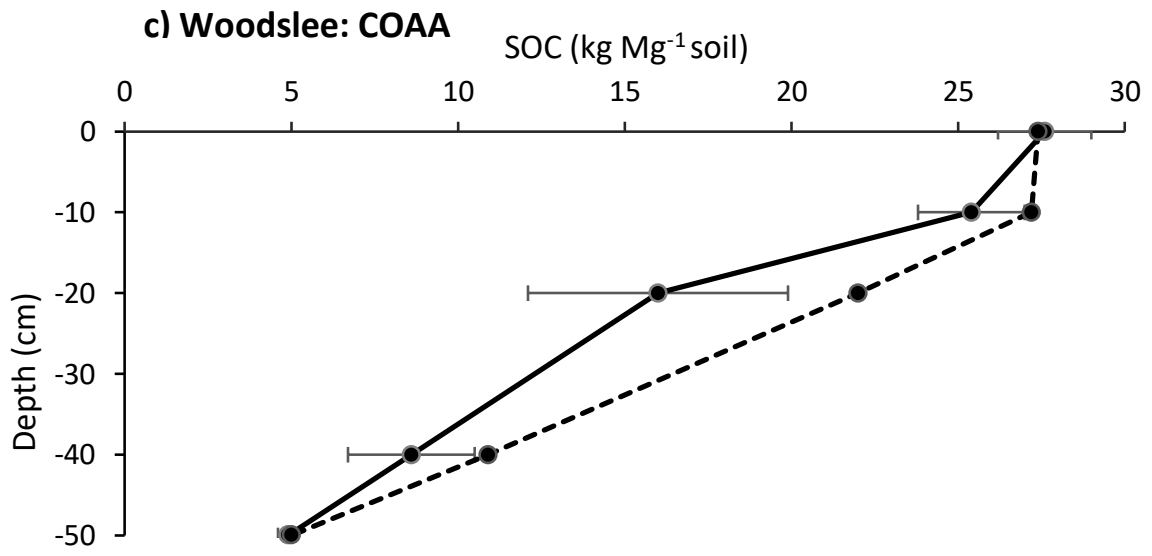

Fig. S2. Observed and DNDC-predicted SOC concentration with depth in a) continuous corn (CC) at Elora, b) continuous corn (CC) at Woodslee and c) corn-oats-alfalfa-alfalfa (COAA) at Woodslee. The horizontal bars represent standard error $(n=4)$ of the mean. Values for Elora are means for 1995, 1998, 2000 and 2005 and for Woodslee 2004-2007. 
a) Elora: $\mathrm{CC}$

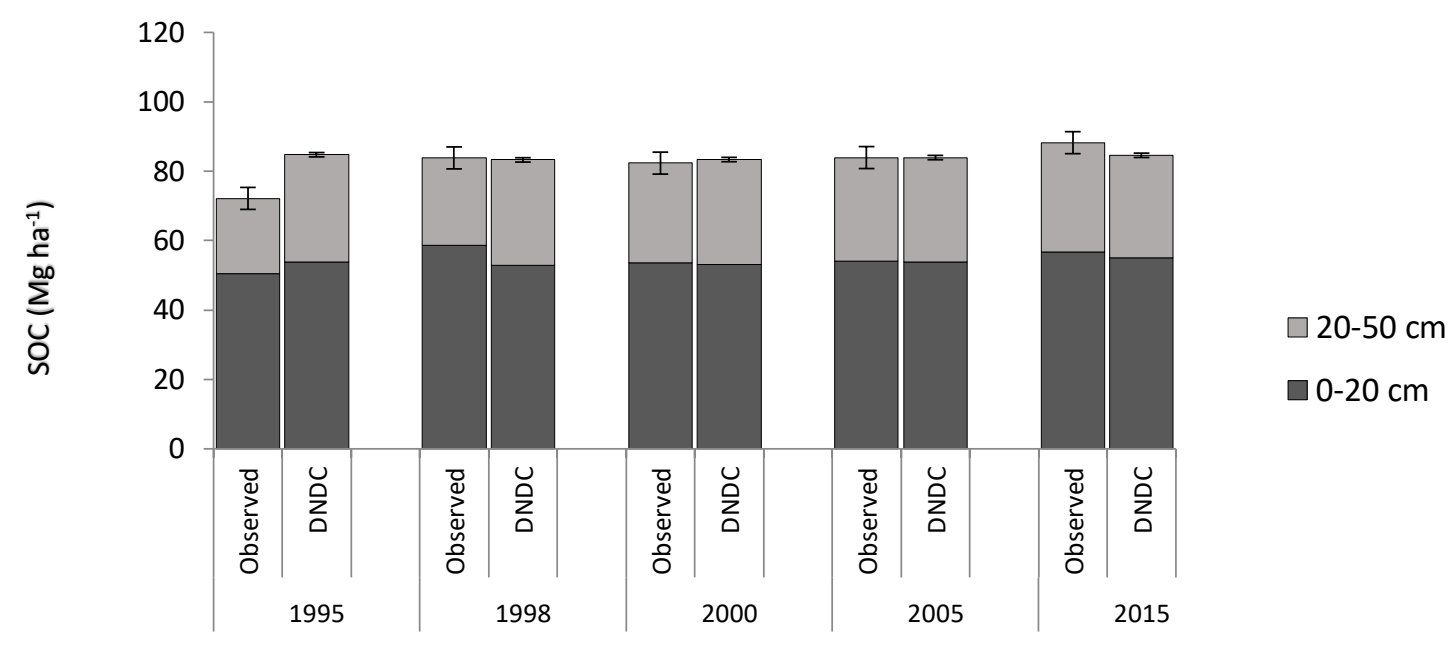

749

750

b) Woodslee:

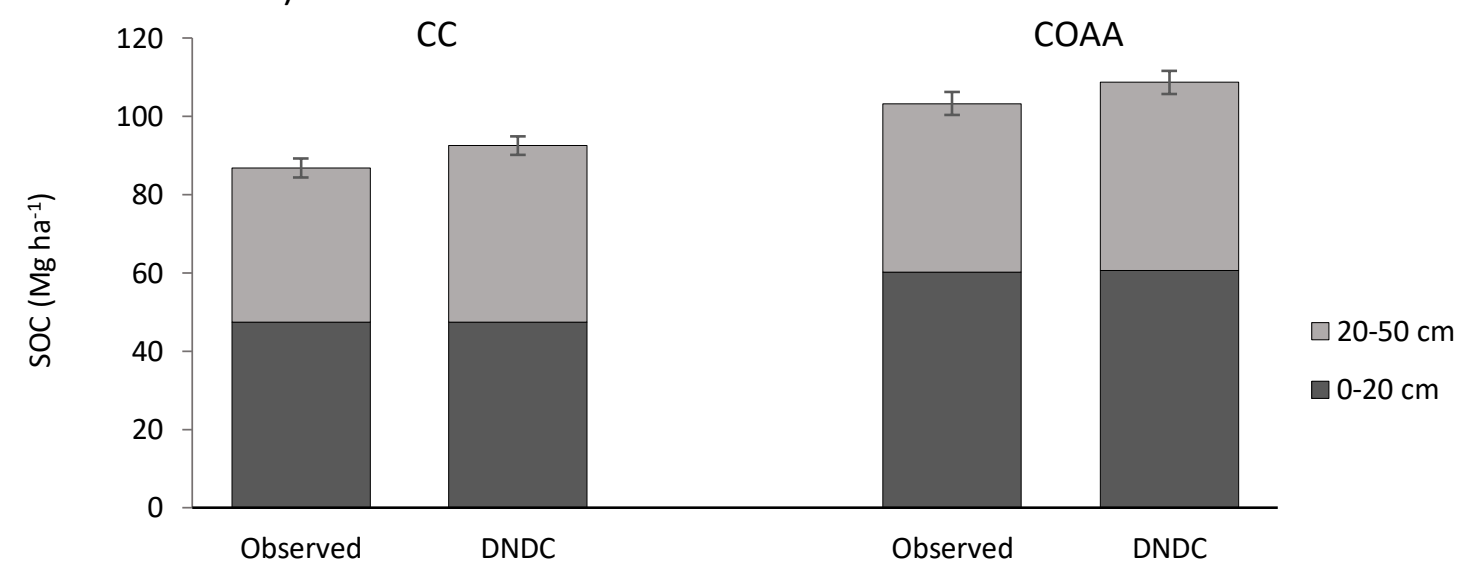

751

752 Fig. S3. Observed and DNDC predicted soil organic carbon (SOC) stock for 0-20 and 20-50 cm 753 layer for a) continuous corn (CC) at Elora, b) continuous corn (CC) at Woodslee and c) corn754 oats-alfalfa-alfalfa (COAA) at Woodslee. Error bars represent standard error ( $\mathrm{n}=5$ for Elora, $\mathrm{n}=3$ 755 for Woodslee). 
Elora

$\square \mathrm{CC} \quad \square \operatorname{ccss} \boxminus \operatorname{ccs} W \quad \mathrm{CCSW}+\mathrm{Rc}$ 目 CCAA
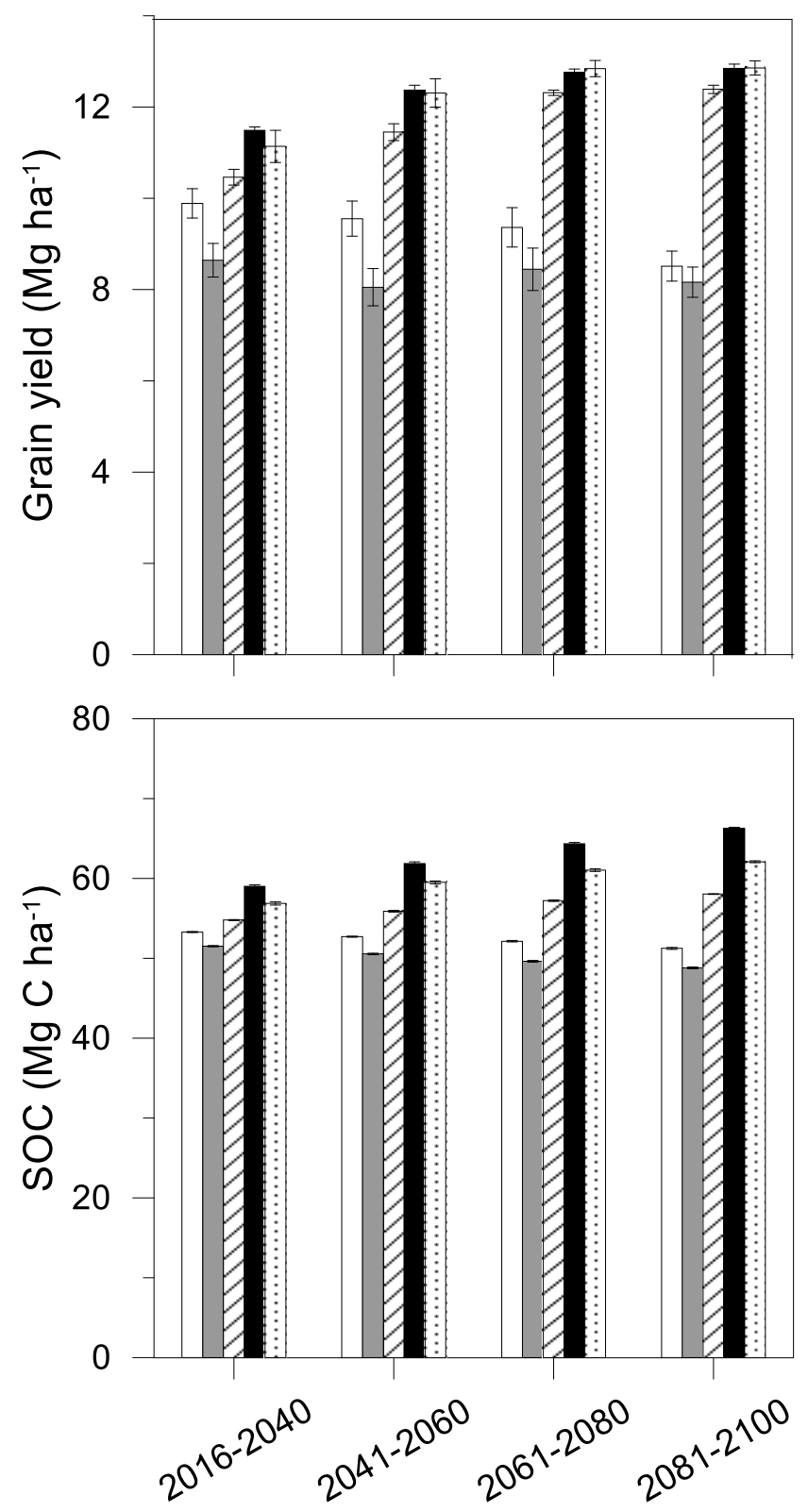

Woodslee

$\square$ CC $\square$ COAA
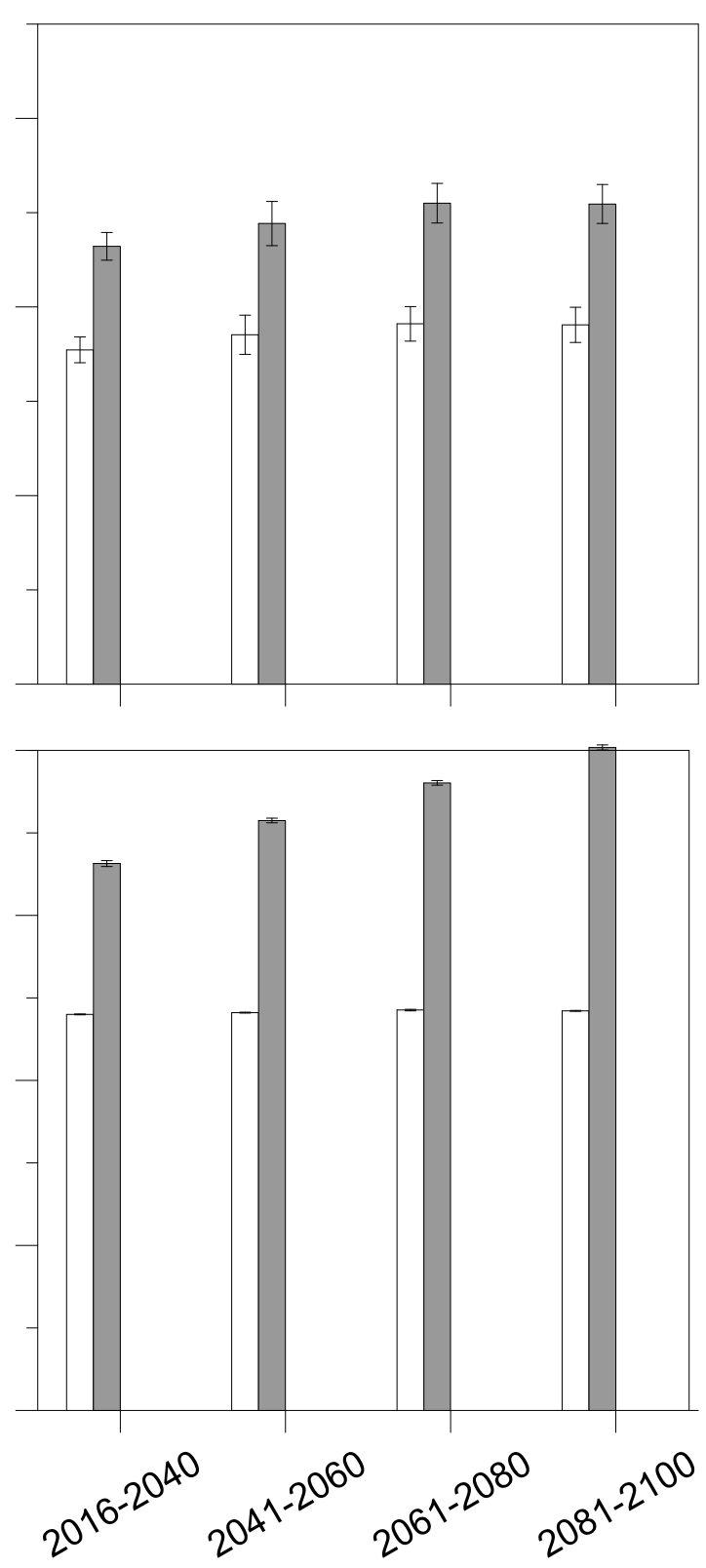

Fig. S4. Predictions of corn yield (top graphs) and 0-0.2 m SOC stock (bottom graphs) under representative concentration pathway (RCP) scenario RCP 8.5 over 2016 to 2100 at Elora (left panel) and Woodslee (right panel) for various cropping systems. Predictions were averaged over selected periods starting in 2016 with error bars representing standard error of means ( $\mathrm{n}=25$ for 2016-2040, and $n=20$ for other periods). CC $=$ continuous corn; CCSS $=$ corn-corn-soybeansoybean, $\mathrm{CCSW}=$ corn-corn-soybean-winter wheat, $\mathrm{CCSW}+\mathrm{Rc}=$ corn-corn-soybean-winter wheat + red clover, CCAA $=$ corn-corn-alfalfa- alfalfa, COAA $=$ corn-oats-alfalfa-alfalfa. 